\title{
BURIAL CUSTOMS BETWEEN THE LATE CHALCOLITHIC AND THE EARLY BRONZE AGE IN THE SHIDA KARTLI REGION OF GEORGIA
}

\section{GÜRCISTAN SHIDA KARTLI BÖLGESINDE GEÇ KALKOLiTiK VE İLK TUNÇ ÇAĞ ÖLÜ GÖMME GELENEKLER̉i}

\author{
Makale Bilgisi | Article Info \\ Başvuru: 27 Ocak 2018 Received: Jenuary 27, 2018 \\ Hakem Değerlendirmesi: 7 Şubat 2018 Peer Review: February 7, 2018 \\ Kabul: 30 Ekim 2018 Accepted: October 30, 2018 \\ DOI Numaras1: 10.22520/tubaar.2018.os.01.003 DOI Number: 10.22520/tubaar.2018.os.01.003
}

\section{Elena ROVA *}

Keywords: Cemeteries, graves, Shida Kartli region, Kura-Araxes culture, Bedeni culture, Martqopi culture, Early Kurgan period, Late Chalcolithic, Early Bronze Age

Anahtar Kelimeler: Mezarlıklar, Mezarlar, Shida Kartli Bölgesi, Kura-Araxes Kültürü, Bedeni Kültürü, Martqopi Kültürü, Early Kurgan Dönemi, Geç Kalkolitik Dönem, İlk Tunç Çă̆

\section{ABSTRACT}

The paper analyses the development of burial customs in the Shida Kartli region of Georgia from the Late Chalcolithic until the end of the Early Bronze Age, especially focusing on the Kura-Araxes culture and on the culture (Martqopi, Bedeni) of the following Early Kurgan period. It summarises available evidence in the light of a recent revision carried out in the framework of the "Georgian-Italian Shida Kartli Archaeological Project" and compares it with contemporary evidence from the neighbouring regions of the Southern Caucasus and of the Upper Turkish Euphrates region. Analogies and differences are highlighted and analysed, with a special attention to the diffusion of barrow graves (kurgans), in the general framework of diachronic developments in interregional relations in the $4^{\text {th }}$ and $3^{\text {rd }}$ millennium $B C$. 


\section{ÖZET}

Makalede Gürcistan Shida Kartli bölgesinde Geç Kalkolitik Dönem'den İlk Tunç Çă̆ı'nın sonuna değin ölü gömme geleneklerinin gelişimi, özellikle Kura-Aras ve daha sonraki Erken Kurgan Dönemi (Martqopi, Bedeni) kültürleri çerçevesinde incelenmiştir. "Georgian-Italian Shida Kartli Archaeological Project" çatısı altında gerçekleştirilmiş olan son bir revizyonunun ışı̆̆ındaki bulgular ve komşu bölgeler Güney Kafkasya ve Türkiye Yukarı Fırat Havzası'ndaki çağdaşlarıyla karşılaştırarak özetlenmiştir. Karşılaş̧ırmalar ve farklılıklar, kurganların yayllımına özel bir dikkat göstererek MÖ 4-3. binyıllarda bölgelerarası ilişkilerin tarihi gelişiminin genel çatısı altında belirtilmiş ve analiz edilmiştir. 


\section{INTRODUCTION 1}

The recent intensification of field research in the different countries of the Southern Caucasus and the availability of an increasing number of ${ }^{14} \mathrm{C}$ dates have deeply affected research about the Kura-Araxes culture (henceforward, $\mathrm{KA})^{2}$ and its relations with the earlier, local cultures of the Chalcolithic period and with those of the later Early Bronze $\mathrm{Age}^{3}$. The dating of the Maikop culture of the Northern Caucasus to the $4^{\text {th }}$ mill. BC and the discovery of South-Caucasian Late Chalcolithic horizons (Leilatepe, Berikldeebi) with North-Mesopotamian and North-Syrian connections ${ }^{4}$ have opened up new perspectives on the origins of the KA culture ${ }^{5}$, while the relations of the latter with the cultures (Martqopi, Bedeni) of the so-called Early Kurgan period are also the object of much recent scholarly debate ${ }^{6}$. Finally, new attention has also been paid to regional and local variability within the at first sight very homogeneous KA cultural complex ${ }^{7}$.

As concerns burial customs, it is now obvious that the traditional view, according to which monumental barrow graves (kurgans) were introduced in the Southern Caucasus in the mid- $3^{\text {rd }}$ millennium (hence the traditional name, Early Kurgan period, attributed to the post-KA phase) is no longer valid, since kurgans were already known in the region in the mid- $4^{\text {th }}$ millennium $\mathrm{BC}^{8}$. While it remains in general terms

\footnotetext{
${ }^{1}$ Acknowledgements. This article is a revised version of the paper presented at session T01S031 (Connecting seas - across the borders. Changes and Developments in Burial Customs in the Eastern Anatolia and Southern Caucasus from Late Chalcolithic to Late Iron Age) of the EAA congress in Istanbul (10-14 September 2014). I am grateful to the organisers of the session for inviting me to take part in the session. I am also grateful to Aynur Özfirat, who kindly translated the abstract and figure captions into Turkish for me, to Zviad Sherazadishvili, who suggested some bibliographic sources, and to Davit Darejanashvili, who helped with translations from Russian and Georgian.

2 For an updated review of research about the KA culture, see Chataigner/Palumbi 2014.

3 Following the terminology commonly in use among Near Eastern archaeologists (see, e.g., Lyonnet 2007: 13, tableau 1), we consider the Late Chalcolithic period as roughly equivalent to the late $5^{\text {th }}$ and $4^{\text {th }}$ millennium BC (Rothman 2001), and the Early Bronze Age as approximately corresponding to the $3^{\text {rd }}$ millennium $\mathrm{BC}$ as defined, for instance, by the ARCANE international project (http://www.arcane.uni-tuebingen.de/presentation.html).

4 For an overview of recent research, see different contributions in the collective volumes Lyonnet 2007; Hansen/Hauptmann/ Motzenbäcker/Pernicka 2010; Rova/Tonussi 2017.

5 See, most recently, Sagona 2014.

6 Among others, Bertram 2003; Bertram 2005; Bertram 2010; Puturidze 2012; Puturidze/Rova 2012; Rova 2014; Rova/ Makharadze/Puturidze 2017 and other contributions in Rova/ Tonussi 2017.

7 Chataigner/Palumbi 2014.

8 E.g. at Soyuk Bulak in Azerbaijan and at Kavtiskhevi in Georgia: Akhundov 2007; Lyonnet/Akhundov/Almamedov 2008; Makharadze 2007.
}

true that conspicuous accumulations of gravegoods in individual graves are missing in KA contexts, it became evident that the KA culture exhibits a wide diversity of funerary practices $^{9}$, and it is not always easy to understand whether these are connected to chronological evolution, regional variability, a combination of both, or to still other factors.

The Shida Kartli region in the central part of present-day Georgia belongs to what is traditionally considered the heart of the KA culture, and hosts a relatively high number (ca 20) of excavated sites of the KA period ${ }^{10}$. Besides settlements, cemeteries and/or individual graves are also well represented and well distributed within the region (Fig. 1); in addition, funerary evidence for the preceding Late Chalcolithic cultures and for the following Early Kurgan cultures is also available for the area, which therefore offers a good opportunity to analyse the diachronic developments of burial customs at a regional level.

KA funerary evidence from the Shida-Kartli region has been recently revised by the "Georgian-Italian Shida Kartli Archaeological project" of Ca' Foscari University in collaboration with the Georgian National Museum, on the occasion of the final publication of the KA cemetery of Khashuri Natsargora ${ }^{11}$. We will present here an updated summary of the evidence discussed in 2012, integrated by a review of the data concerning the pre- and postKA periods in the region ${ }^{12}$.

\section{KURA-ARAXES BURIALS IN SHIDA KARTLI}

The Shida Kartli corpus amounts to 90 published graves: 26 from Natsargora ${ }^{13}, 19$ from Kvatskhela/Tvlepias Tsqa$\mathrm{ro}^{14}$; 13 from Aradetis Orgora/Doghlauri ${ }^{15}, 12$ from Dzaghina $^{16}, 9$ from Urbnisi ${ }^{17}, 3$ from Takhtidziri ${ }^{18}$ and from Tquiavi ${ }^{19}$, and 1 from $\mathrm{Nuli}^{20}$; one should however be

9 Poulmarc'h/Pecqueur/Jalilov 2014; Poulmarc'h 2014; see also Palumbi 2007-2008; 2008: 139-143, 157-210, passim.

${ }^{10}$ Rova 2014; see also Japaridze 1992, passim; Kushnareva 1997 : 46-47, 59-61.

${ }^{11}$ Puturidze/Rova 2012 (see especially Jalabadze/Ghlonti/Kroidze/Ketskhoveli/Chilashvili 2012).

${ }^{12}$ In the meanwhile, see also Rova 2014: 57-59, 64-65.

${ }_{13}$ Puturidze/Rova 2012.

${ }^{14}$ Javakhishvili/Glonti 1962; Glonti/Ketskhoveli/Palumbi 2008; Jalabadze/Ghlonti/Kroidze/Ketskhoveli/Chilashvili 2012: 6070 .

${ }^{15}$ Koridze, Palumbi 2008; Jalabadze/Ghlonti/Kroidze/Ketskhoveli/Chilashvili 2012: 75-82.

${ }^{16}$ Kuftin 1974; Japaridze 1961; Jalabadze/Ghlonti/Kroidze/Ketskhoveli/Chilashvili 2012: 84-90.

${ }^{17}$ Chilashvili 1964; Kikvidze 1972; Jalabadze/Ghlonti/Kroidze/ Ketskhoveli/Chilashvili 2012: 70-74.

18 Jalabadze/Palumbi 2008; Jalabadze/Ghlonti/Kroidze/Ketskhoveli/Chilashvili 2012: 82-84.

${ }^{19}$ Makhalatia 1943; Jalabadze/Ghlonti/Kroidze/Ketskhoveli/Chilashvili 2012: 90.

${ }^{20}$ Japaridze 1955; Jalabadze/Ghlonti/Kroidze/Ketskhoveli/Chilas- 


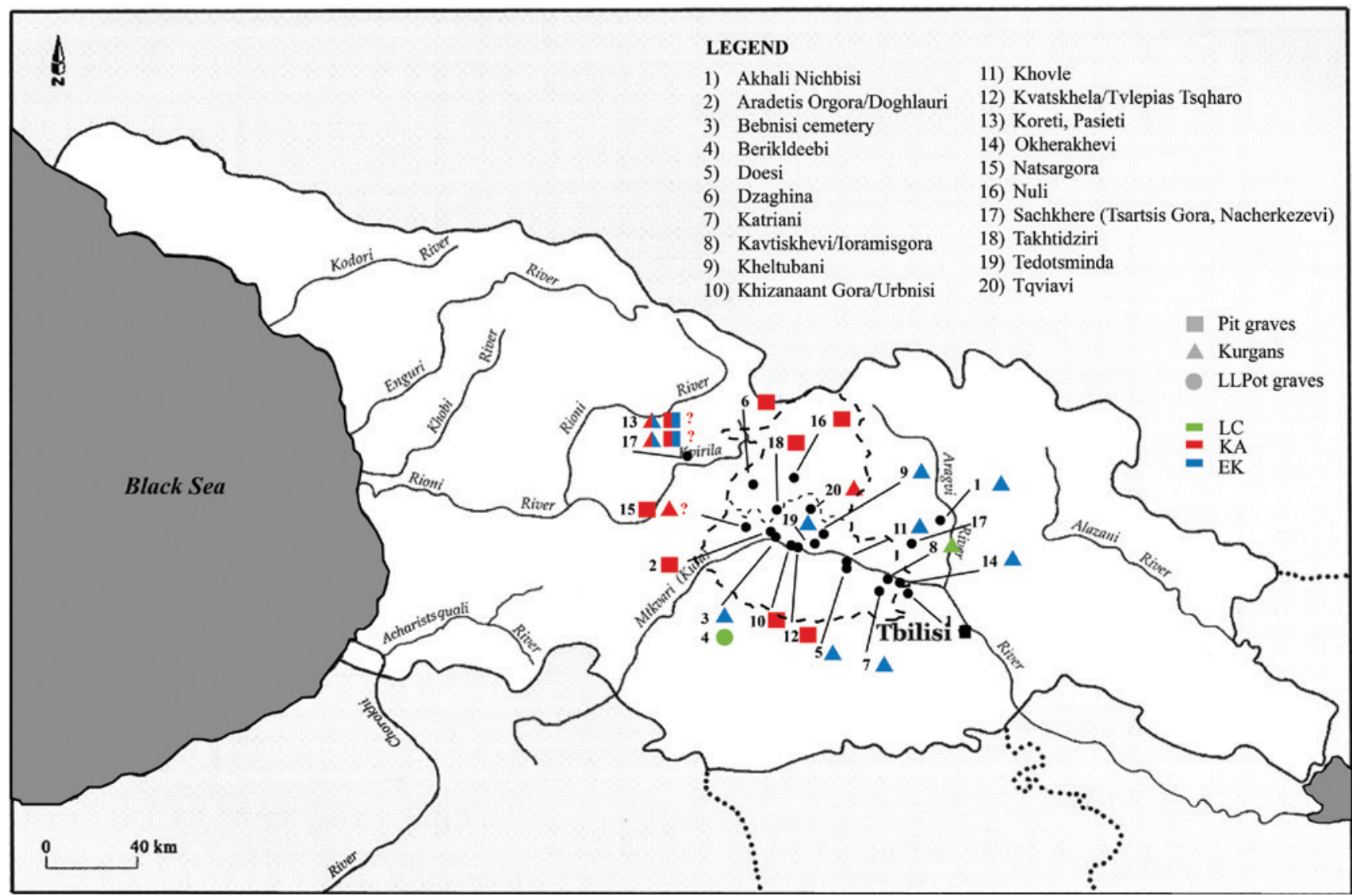

Figure 1: Map of Georgia with Administrative Limits of the Shida Sartli Province and Approximate Location of the Archaeological Sites Mentioned in the Text (modified from Sagona/Abramishvili 2008). / Gürcistan Haritası, Metinde Geçen Arkeolojik Alanların Yaklaşık Lokasyonu ve Shida Kartli İlinin İdari Sinırlarl (Sagona/Abramishvili 2008'den düzenleme).

aware of the presence of important still unpublished data: e.g., more than 60 new KA graves have been excavated during the last few years at the Aradetis Orgora/Doghlauri cemetery ${ }^{21}$. Due to the strong continuity of the regional material culture, it is not easy to date these graves on the basis of their burial goods. Pottery assemblages, for instance, are composed of a few, rather simple types, which show a high individual variety but little diachronic variation, and the same is valid for the remaining finds. It appears however that none of the graves belongs to the earliest phase of the culture ${ }^{22}\left(\mathrm{KA} \mathrm{I}, 3^{\text {rd }}\right.$ quarter of the $4^{\text {th }}$

\section{hvili 2012: 90}

${ }^{21}$ Gagoshidze 2012; for a preliminary plan of the cemetery (KA graves marked in blue) see also Gelashvili 2014: 210, pl. 1. When this article was written, excavation at Doghlauri cemetery were still in progress, under the direction of Iulon Gagoshidze, in the framework of a salvage excavation for the building of the new Tbilisi-Senaki-Leselidze highway. The last field season took place in June/July 2015. In the meanwhile, the material from the Kura-Araxes graves excavated at Doghlauri during the 2012-2015 seasons has been fully processed (in 2017) by a joint Georgian-Italian team in the framework of the "Georgian-Italian Shida Kartli archaeological project".

${ }^{22}$ As far as it can be deduced from the descriptions of published examples, the presence of Monochrome Ware, which characterises the KA I phase, is rather rare, while pottery assemblages are mill. BC), while the majority date, possibly with slight chronological differences among them ${ }^{23}$, to its central phase (KA II, 3200-2800 BC ca), and only few of them (namely some of those from Aradetis Orgora/Doghlauri) to the later phase (KA III, possibly between 2800 and $2600 \mathrm{BC} \mathrm{ca})^{24}$. As an example (Fig. 2), we show some ceramic assemblages from KA II (to the left) and from KA III graves (to the right): typical features of the later phase being the presence of slightly raised bases, pots with accentuated belly marked by a slight carination both under and over it, and the presence of incised decoration.

\section{CEMETERIES LOCATION AND INTERNAL ORGANISATION}

"Extra-moenia" cemeteries, usually situated in close proximity to the contemporary settlement, appear to have

dominated by Red Black Burnished Ware, which represents the typical hallmark of the KA II phase, and Black Burnished Ware (a generally later feature) is only occasionally attested.

${ }^{23}$ Thus, the cemeteries of Kvatshela, Natsargora and Dzaghina West may represent a slightly earlier, those at Urbnisi, Takhtidziri and Dzaghina East a slightly later sub-phase (cf. Puturidze/ Rova 2012: 46, 97 f.).

${ }^{24}$ For the internal periodisation and chronology of the KA culture in the Shida Kartli region, see Rova 2014. 


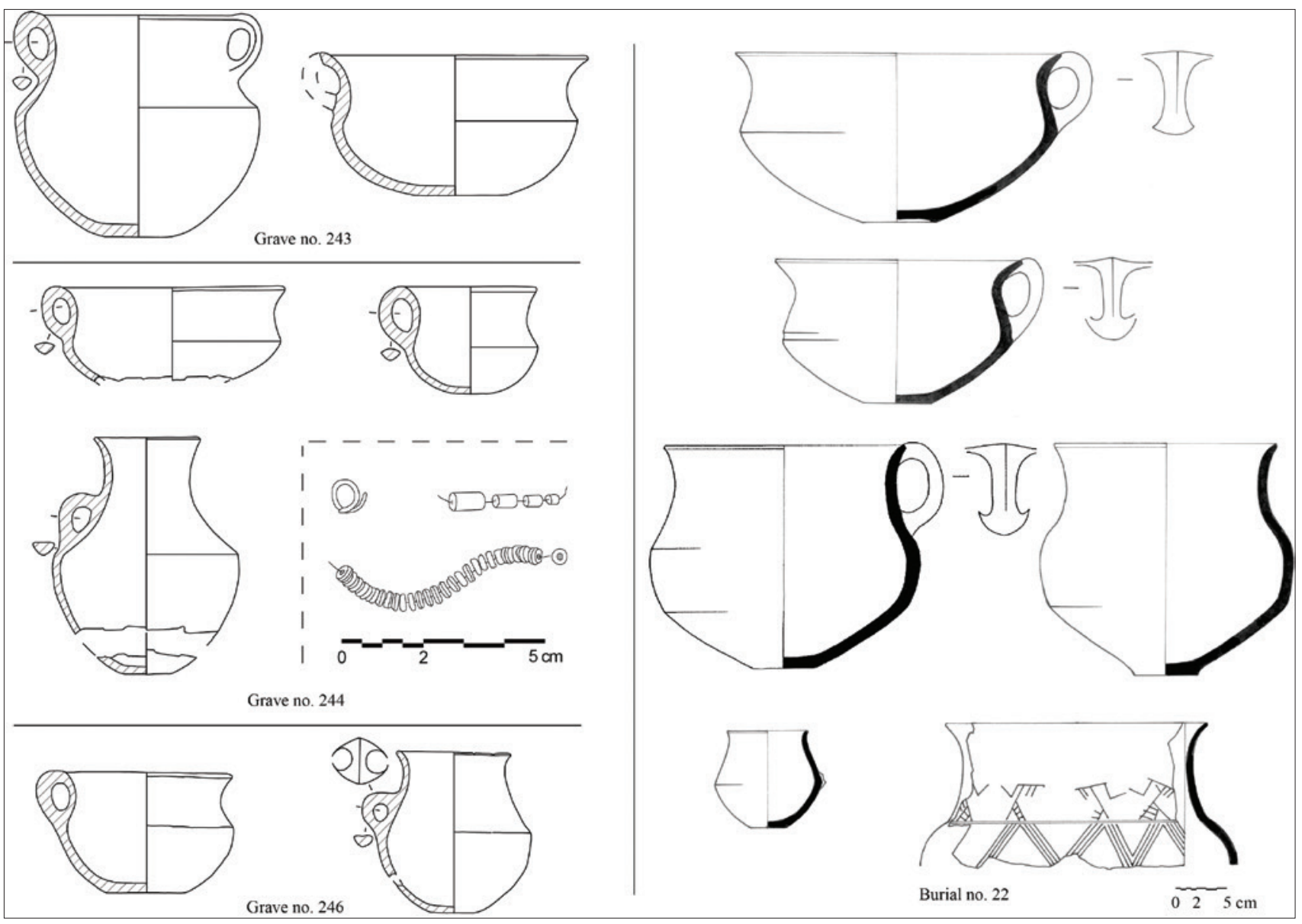

Figure 2: Examples of Ceramic Assemblages from KA II (left: Khashuri Natsargora, graves Nos. 243, 244, 246: from Puturidze/Rova 2012: Fig. 3) and KA III Graves (right: Aradetis Orgora/Doghlauri: grave 22: from Puturidze/Rova 2012: Fig. 30). / KA II Çanak Çömlek Örnekleri (sol: Khashuri Natsargora, 243, 244, 246 no'lu mezarlar: Puturidze/Rova 2012: Fig. 3) and KA III Mezarlarl (să̆: Aradetis Orgora/Doghlauri: 22 no'lu Mezar: Puturidze/Rova 2012: Fig. 30).

been the usual location for graves: in fact, single isolated burials are virtually unattested in the published documentation $^{25}$. The recovery, in two cases, of human remains on the Natsargora settlement mound allows to hypothesise that intra-moenia depositions may have been carried out in exceptional cases $^{26}$. In both cases the bones apparently lay in simple, informal pits; neither was equipped with any burial goods. It is interesting to observe that in both examples the remains belonged to adult individuals; the

\footnotetext{
${ }^{25}$ The single KA grave from Nuli, for instance, was also found in a cemetery area.

${ }^{26}$ The first had been found during the 1980s excavations at the site by Al. Ramishvili (Puturidze/Rova, in preparation; see, in the meanwhile, Ramishvili 2013: 56, pl. XVI, 2). The complete skeleton lay in crouched position on the bottom of a KA pit located on the northern slope of the mound. The second one (still unpublished) was a disturbed grave (?) found during the 2011 excavations at the site by the Georgian-Italian Shida Kartli Archaeological Expedition: the abruptly truncated femurs and the feet of an adult skeleton were lying on a burnt layer which covered the prepared floor of a KA open area, a few cm under the present surface of the mound. If this was indeed a grave, the position of the bones could suggest that the dead was originally lying on the back.
}

comparatively widespread custom of burying newborn and infants inside the settlement - often even within the surface of the houses (intra-moenia/intra muros graves) - thus appears not to have been practiced by the KA communities of the Shida Kartli region.

In most instances - at Khashuri Natsargora, Aradetis Orgora/Doghlauri, Kvatskhela/Tvlepias Tsqaro and Khizanaant Gora/Urbnisi, but possibly at further sites as well ${ }^{27}$ - the cemetery was clearly associated with a nearby settlement (Fig. 3): typically, it was located on a flat area divid-

${ }^{27}$ At Tsikhiagora, for instance, a concentration of pottery sherds to the west of the settlement mound, beyond a small watercourse, may suggest the original location of the KA cemetery (Z. Makharadze, personal communication). On the other hand, at Takhtidziri, the remains of an occupational layer of an earlier phase (KA I) of the KA culture were found under the KA II period graves (Jalabadze et al. 2012: 82): in this case the settlement may have just shifted its location to a nearby area in the course of time, like at Kvatskhela (see infra). A similar situation was met with at Dzaghina, where some pits yielding KA materials were found not far from the graves (Jalabadze/Ghlonti/Kroidze/Ketskhoveli/ Chilashvili 2012: 90-92). 

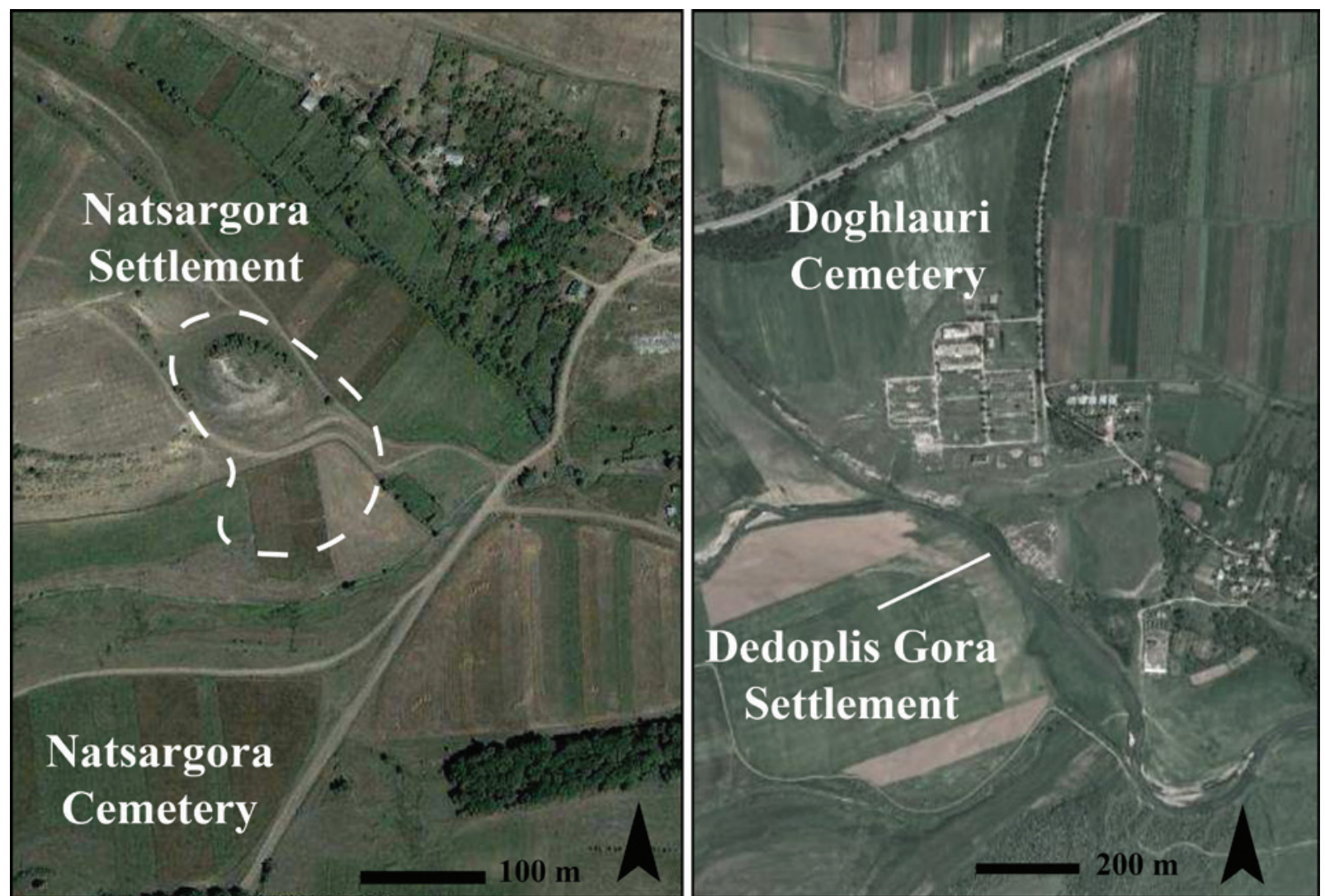

Figure 3: Location of the Natsargora and Doghlauri Cemeteries (modified from Google Earth). / Natsargora ve Doghlauri Mezarlıklarının Lokasyonu (Google Earth'den düzenleme).

ed from the settlement by a small course of water ${ }^{28}$. Unequivocable evidence for cemeteries located far from any contemporary settlement is hitherto missing, since even in cases where only burials were published, the possibility cannot be ruled out that the relevant settlement has not yet been discovered, or has been completely destroyed.

None of the cemeteries was completely excavated, but it can be assumed that they generally were of rather small size: Doghlauri may have been one of the largest ones, a fact which well corresponds to the importance of the neighbouring settlement of Aradetis Orgora, which was one of the main centres of the Shida Kartli region ${ }^{29}$. At multiperiod sites (e.g. at both Aradetis Orgora and Natsargora) the area of the KA cemetery was used as a burial ground during the later periods of occupation as well, most notably during the Late Bronze Age and the Classical period; a fact which on the one hand probably caused the loss of a number of KA graves, and on the other one obscures the limits of the extension of the original KA cemetery, and makes the patterns of spatial distribution of the KA graves difficult to grasp ${ }^{30}$ (Fig. 4).

${ }^{28}$ E.g. at Natsargora and Aradetis Orgora/Doghlauri and possibly as well at Tsikhiagora (see supra, fn. 27).

${ }^{29}$ Gagoshidze/Rova 2018; see also Rova 2014: 51.

${ }^{30}$ At Natsargora, for instance, only 26 out of the more than 500 excavated graves could be attributed to the KA period, while the vast majority date back to the Late Bronze/Early Iron Age (ca. 150

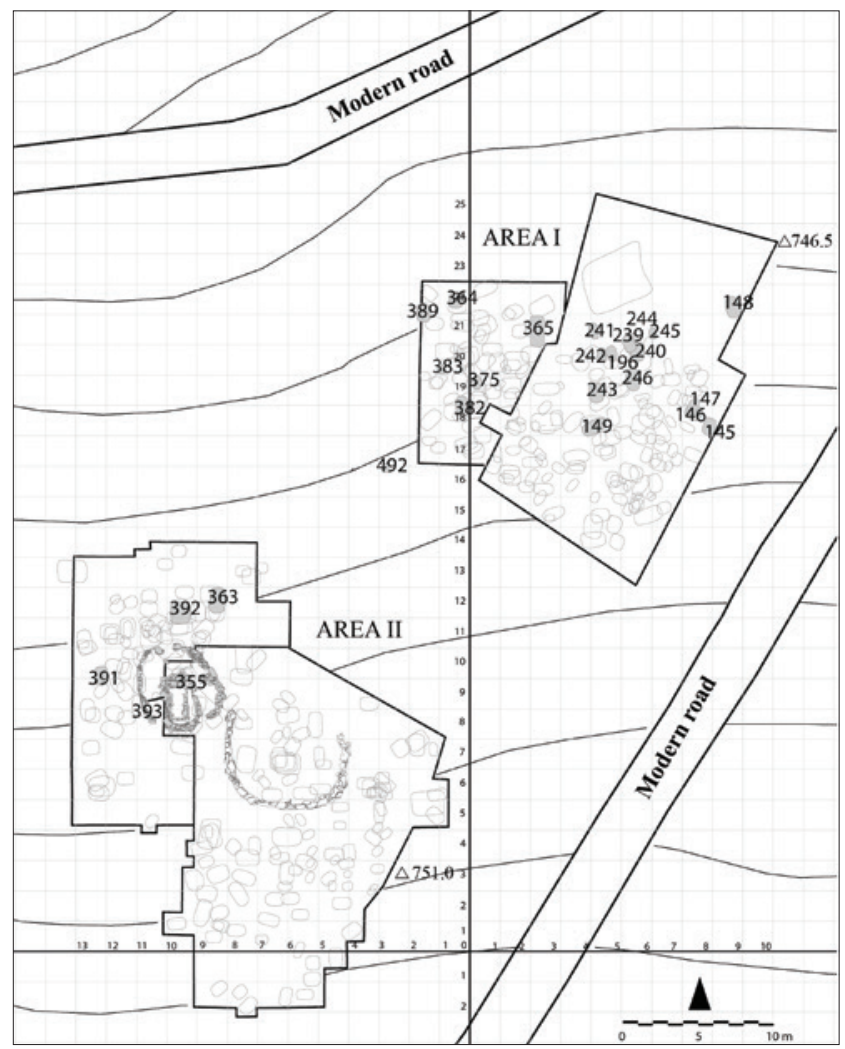

Figure 4: Plan of the Natsargora Cemetery Area with Approximate Limits of the Excavation Trenches (EBA Graves Highlighted) (from Puturidze/Rova 2012: Pl. 8, Updated from Ramishvili 2013: Pl. II). I Açmaların Yaklaşık Sinırlarıyla Natsargora Mezarlık Alanı Planı (ITTÇ Mezarları Işsaretlenmiş) (Puturidze/ Rova 2012: Pl. 8, Ramishvili 2013: Pl. II'den Güncellenmiş). 

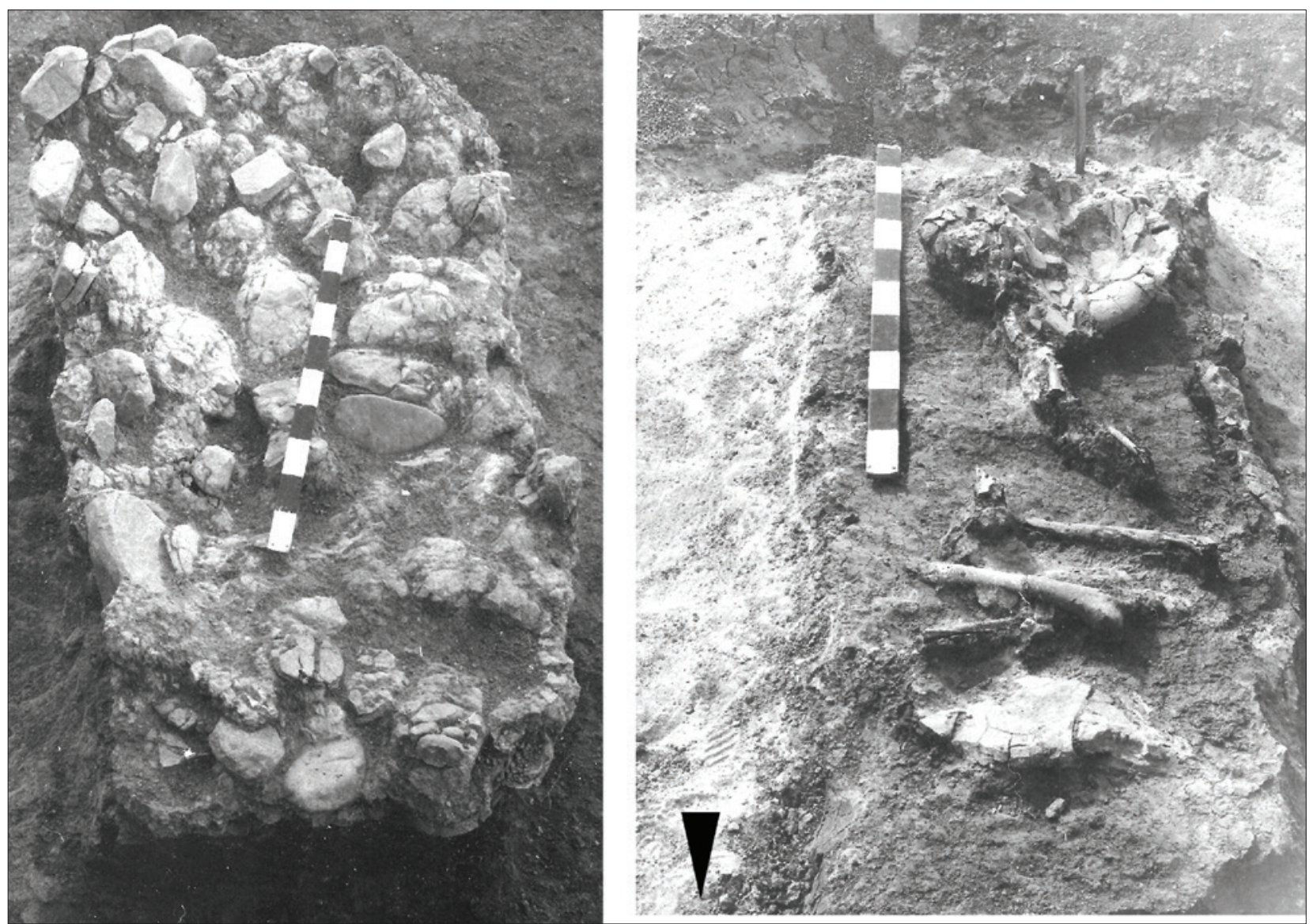

Figure 5: Grave No. 365 from Natsargora: Group of Stones (Left) and Burial (Right) (from Puturidze/Rova 2012: Pl. 23). / Natsargora 365 No'lu Mezar: Mezarın Taş Örtüsü (Sol) ve Mezar (Sağ) (Puturidze/Rova 2012: Pl. 23).

The case of Kvatskhela suggests that the location of the village cemetery could change in the course of time: there, the early cemetery lay at the northern edge of the settlement, and was partially covered by the village's expansion, while the later one lies on a little promontory (Tvlepias Tsqaro), ca $250 \mathrm{~m}$ to the north-east. Although detailed information about the cemeteries' internal stratigraphy is generally missing, several lines of reasoning lead to hypothesise that most of them were in use for a relatively short time ${ }^{31}$ : thus, KA graves only rarely cut each other, and in some cases they appear to follow an intentional alignment ${ }^{32}$; furthermore, burial goods tend to be rather similar in all the graves of each cemetery.

graves) and to the Classical period (ca. 350 graves).To judge on the basis of the distribution of the excavated KA graves (see Fig. 4) the $3^{\text {rd }}$ millennium burial ground probably occupied the sector of the cemetery located closer to the settlement mound.

31 Thus, at Natsargora it could be observed that KA graves were only rarely cut by contemporary graves, as if the position of the earlier graves was still known when the later ones had been dug. It was also observed that, as far as it could be reconstructed, most of the graves were lying at approximately the same depth from the surface (see Puturidze/Rova 2012: 27).

32 This seems to be the case, for instance, at Kvatskhela and Aradetis Orgora (Jalabadze/Ghlonti/Kroidze/Ketskhoveli/Chilashvili 2012, fig. $11 \mathrm{~b}, 28$ ), though, interestingly enough, not at Natsargora (see Fig. 4).

\section{BURIAL CUSTOMS}

Compared to other regional variants of the KA culture, the Shida Kartli variant stands out for a very strong homogeneity in burial customs ${ }^{33}$. Typically, KA graves in Shida Kartli are simple pit graves in rectangular or slightly oval pits, normally less than $1 \mathrm{~m}$ deep, occasionally lined with stones on all or on two or three sides, and generally covered by a low irregular group of stones (Fig. 5) . $^{34}$.

Stone cist graves, frequent in Kvemo Kartli, Armenia and SE Turkey, and horseshoe-shaped ones, attested in Kvemo Kartli and Armenia ${ }^{35}$, are completely ab-

\footnotetext{
33 See Puturidze/Rova 2012: 29-38, 96; Rova 2014: 57-59.

${ }^{34}$ Poulmarc'h 2014 attributes these graves to three different types: pit burials - tombes en fosses -, stone tombs of variable shape - tombes de formes variables -, where she would classify the stone-lined graves - tombs covered by heaps of stones - tombes signalée en surface par un amas de pierres -. In fact, however, both simple pit graves and stone-lined graves are often covered by a heap of stones and, furthermore, the distinction between the former two types is often rather vague.

35 On KA burial customs, see Palumbi 2007-2008: 21-35; 2008: 136-144 et passim; Sagona 2004: 480; Poulmarc'h 2014; Poulmarc'h/Pecqueur/Jalilov 231-242.
} 
sent in the region, and stone constructions of other types are reported only in rare cases ${ }^{36}$. "Kurgans" are, though rarely, attested (they will be discussed in a separate paragraph below), but not as frequently as, e.g., in contemporary Azerbaijan, where they apparently represent the dominant type of grave in the KA period $^{37}$.

Individual graves of adults are numerically dominan $t^{38}$. Double or triple inhumations are, though not very frequently, attested; they often contain the remains of at least one child. Collective burials with more than three skeletons, as often found among other KA communities of the Southern Caucasus $^{39}$, are, on the contrary, apparently rather rare in the Shida Kartli region ${ }^{40}$.

The body was generally lying directly under the stones, but in a few cases ${ }^{41}$ the burial pit may have been covered by a wooden roof. One is clearly dealing in most cases with primary depositions, as shown by the fact that the bones are generally found still in anatomical connection. Orientation and position of the body were apparently governed by very strict rules: the skeleton almost invariably lay in crouched position on one side, generally with both hands in front of the hoveli/Chilashvili 2012: 83 f., fig. 42a, grave no. 35) was somehow unusual, in that it appeared to be provided with a false-vault roof, and was equipped with an ogive-shaped step on one of the short sides.

${ }^{37}$ Poulmarc'h/Pecqueur/Jalilov 2014: 237-244. In general on $\mathrm{Ku}-$ ra-Araxes kurgans, see also Poulmarc'h 2014: 96-101.

${ }^{38}$ It should be considered that calculations about the number of bodies per grave may be biased by the fact that in many cases the graves were disturbed and the human bones were poorly preserved and that, in the case of older excavations, human remains have not been analysed by a physical anthropologist. For this reason it is difficult, for instance, to speculate about the meaning of the occasional presence of apparent exceptions, e.g. cenotaphs - Natsargora, grave no. 383 (Puturidze/ Rova 2012: 32), Aradetis Orgora burial no. 27 (Jalabadze/Ghlonti/Kroidze/Ketskhoveli/Chilashvili 2012: 78) or intentional depositions of selected parts of the body - e.g. Natsargora, grave no. 393 (Puturidze/Rova 2012: 32).

${ }^{39}$ E.g. at Samshvilde, Koda and Kiketi in Georgia (Palumbi 2008: 141), and at Keti in Armenia (Palumbi 2008: 139). In particular, KA kurgans in Azerbaijan (Poulmarc'h 2014: 351 et passim) systematically host collective graves.

${ }^{40}$ A few examples of graves with more than two inhumations can be mentioned from Natsargora (Grave no. 355, Puturidze/Rova 2012:18-20, figs. 4-5, pls. 17-19); Aradetis Orgora (Graves nos. 22, 25, 29: Jalabadze/Ghlonti/Kroidze/Ketskhoveli/Chilashvili 2012; Koridze, Palumbi 2008: passim) and Kvatskhela (Graves nos. 6 and 12: Jalabadze/Ghlonti/Kroidze/Ketskhoveli/Chilashvili 2012; Glonti/Ketskhoveli/Palumbi 2008: passim). In this connection, mention should also be made of Kurgan no. 1 at Tqviavi, which contained the remains of 42 individuals (Jalabadze/Ghlonti/Kroidze/Ketskhoveli/Chilashvili 2012).

${ }^{41}$ Natsargora, graves nos. 240, 363 f., 66, Kvatskhela graves nos. 7, 10, 15 (Puturidze/Rova 2012: 15, 21, 29, 63, 64). face, oriented in north-south or northwest-southeast direction, parallel or at a slight angle with the burial pit's long wall, with the head pointing south ${ }^{42}$ (Figs. 5, 6). Although at a general regional level the majority of the bodies were lying on the right side, significant differences were observed in this respect between different cemeteries ${ }^{43}$.

The fate of the remains of newborn and young children is unclear. They were apparently not intended to be regularly buried in the cemeteries ${ }^{44}$, except for cases in which they accompanied the grave of an adult ${ }^{45}$. On the other hand, they do not appear to have been regularly buried within the settlements, either, following a widespread use in prehistoric societies, which is however quite uncommon, and generally interpreted as an archaic feature, in the KA culture ${ }^{46}$.

\section{BURIAL GOODS}

Burial goods were generally rather modest, and mainly consisted of a small number of pottery vessels ${ }^{47}$. In particular, the presence of an open and of a closed vessel is a constant feature at a regional level; it seems reasonable to think that they represented a sort of standard equipment of an adult individual grave, which could be integrated by additional ceramic and non ceramic items. Vessels were almost invariably located between the head and the chest, a position which is suggestive of a laid meal for the dead individual (Figs. $5,6)$.

${ }^{42}$ For details and exceptions, see Puturidze/Rova 2012: 32 et passim.

${ }^{43}$ Ibid.: 35 , fn. 15.

${ }^{44}$ Exceptions are burials no. 7, 14 at Kvatskhela (Jalabadze/Ghlonti/Kroidze/Ketskhoveli/Chilashvili 2012: 63, 66), and maybe burial no. 1 at Tvlepias Tsqaro (Jalabadze et al. 2012: 67).

${ }^{45}$ E.g, in grave no. 240 at Natsargora (Puturidze/Rova 2012: 15 f., 32), burial no. 6 at Kvatskhela (Jalabadze/Ghlonti/Kroidze/ Ketskhoveli/Chilashvili 2012: 62), burial no. 3 at Tvlepias Tsqaro (ibid.: 68), burial no. 22 at Aradetis Orgora (ibid.: 75).

${ }^{46}$ Infants and young children are reported to have been buried under the floors of the buildings at Amiranisgora in the Samtskhe/ Javakheti province of southern Georgia (Jalabadze/Ghlonti/Kroidze/Ketskhoveli/Chilashvili 2012, 69, with relevant literature. A single child jar burial placed beneath the floor of a building was recently found at Chobareti, in the same province (Kakhiani/Sagona/Sagona/Kvavadze/Bedianashvili/Massager/Martın/Herrscher/Martkoplishv1li/B1rkett-Rees/Longford 2013: 17; see also Sagona 2014: 38).

${ }^{47}$ At Natsargora, for instance, the number of vessels in individual graves varied between one and three (Puturidze/Rova 2012: 3335 ); these numbers were also most commonly met with at the other cemeteries of the region in which, however, some cases of graves equipped with four or five, and in one case with seven vessels are also attested (Jalabadze/Ghlonti/Kroidze/Ketskhoveli/Chilashvili 2012: passim). Double or multiple graves were generally equipped with a higher number of pottery vessels than individual ones. 


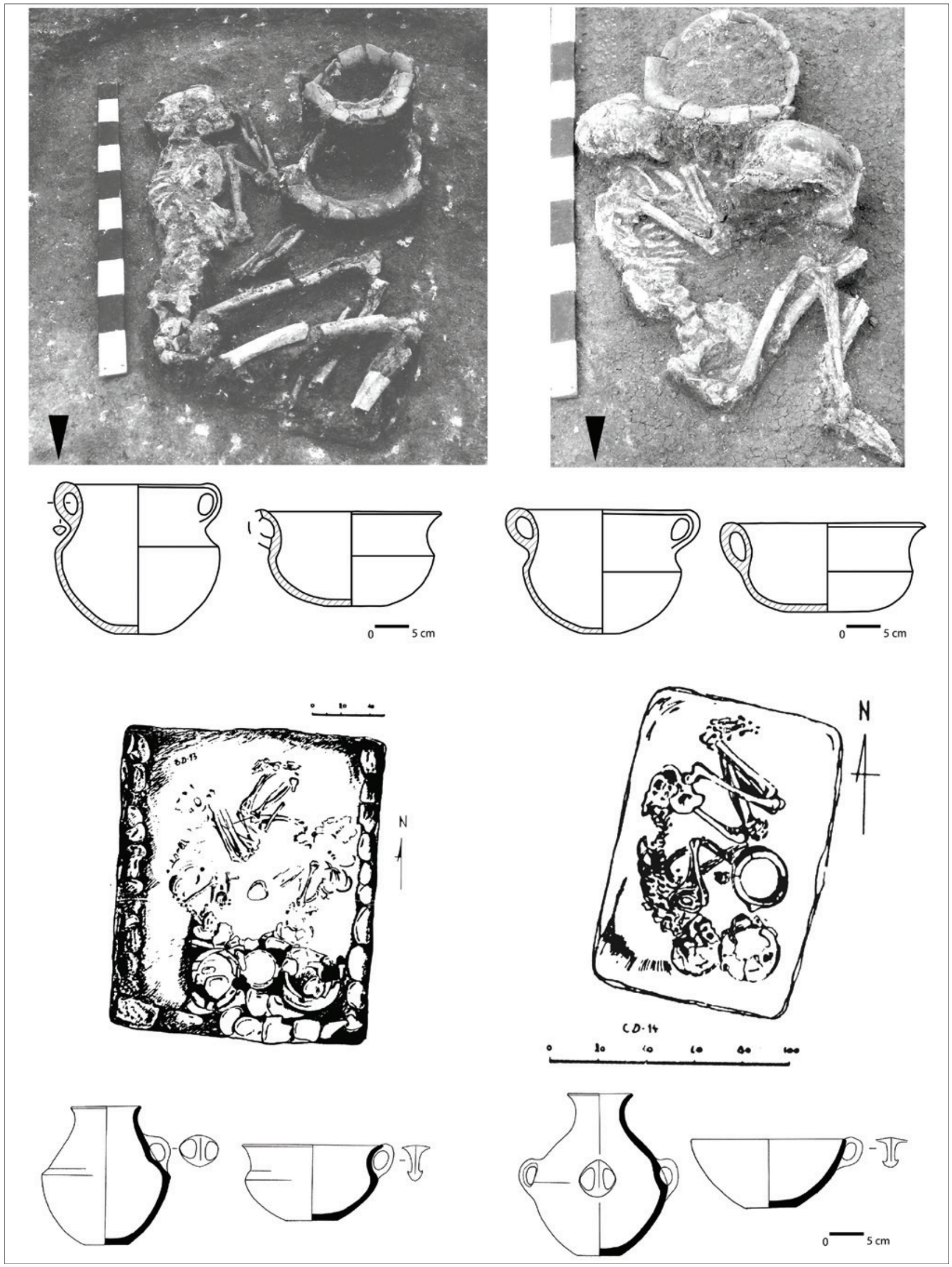

Figure 6: Examples of Kura-Araxes Graves from Shida Kartli: Natsargora, Graves Nos. 243, 391 (from Puturidze/Rova 2012: Pl. 15, 2, Pl. 25, 1, Figs. 3A, Fig. 9A), Above; Kvatskhela, Burials nos. 1, 5 (from Puturidze/Rova 2015: Fig. 13C, 14, 15A), Below. / Shida Kartli'den Bazı Kura-Araxes Mezarlart: Natsargora, 243 ve 391 No'lu Mezarlar (Puturidzel Rova 2012: Pl. 15, 2, Pl. 25, 1, Figs. 3A, Fig. 9A), Yukarıda; Kvatskhela 1 ve 5 No'lu Mezarlar (Puturidze/Rova 2015: Fig. 13C, 14, 15A), Aşă̆ıda. 


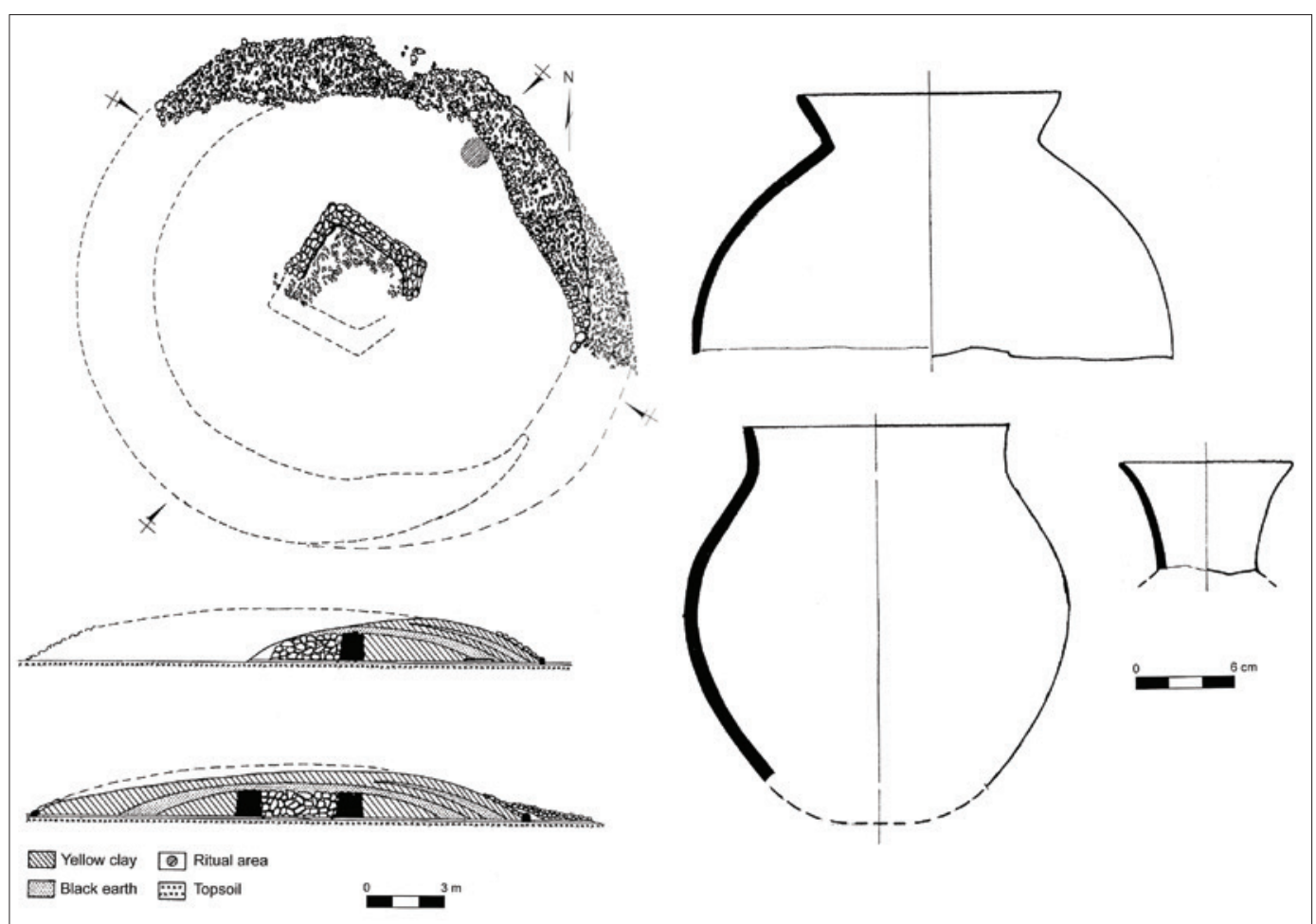

Figure 7: The LC Kurgan at Kavtiskhevi/Ioramisgora (from Makharadze 2008: Figs. 33-34). / Kavtiskhevi/ Ioramisgora LC Kurganı (Makharadze 2008: Figs. 33-34).

Pottery was sometimes accompanied by a few metal ornaments or weapons, by some beads of metal, stone and "paste", and, more rarely, by flint blades or arrow-heads, and bone or clay spindle-whorls. The position of non-pottery goods (these were generally lying directly on the body) suggests that they should be interpreted as personal belongings worn by the deceased rather than as offerings by the survivors.

In general, multiple burials contain a larger amount of items than individual ones, suggesting that the number of gravegoods for each dead did not diverge much. The homogeneity of burial goods and their low number thus appear to confirm the traditional view that one is dealing with a fundamentally egalitarian society, or at least with a society in which differences in status, if existing at all, were not purposely emphasised. The richest grave from the region, grave no. 2 at Kvatskhela, contained the remains of two individuals, probably a male and a female, facing each other in strongly contracted position, accompanied by three pottery vessels. The female (?) skeleton was adorned with a decorated copper diadem and wore a copper bracelet; a large number of copper, carnelian and "paste" beads were found scattered in the area of the chest and neck, and four silver spirals on the back. This grave has often been compared with the contemporary "royal tomb" of Arslantepe ${ }^{48}$, the finds from which actually show re-

\footnotetext{
${ }^{48}$ Frangipane/Di Nocera/Hauptmann/Morbidelli/Palmieri/Sadori/ Schultz/Schmidt-Schultz 2001; Frangipane 2007-2008: 175-
}

markable similarities with those from the Kvatskhela grave and from other burials of the Shida Kartli region, to start with the presence of almost identical "diadems".

However, it has to be pointed out that the number of precious items in the Kvatskhela grave is much lower in comparison to the Arslantepe grave. Moreover, the types of burial goods (exclusively ornaments and pottery) and the fact that they were apparently associated with the female skeleton suggests that aspects other than emerging leadership may have played a role in this case. Diadems, on the other hand, were relatively common in the Shida Kartli region, as shown by the presence of two similar ones at Gudabertka settlement ${ }^{49}$.

\section{PRE - AND POST - KURA-ARAXES FUNERARY EVIDENCE IN SHIDA KARTLI}

We can now proceed to compare this picture with what is known about burial customs in the Shida Kartli region during the pre- and post-KA periods. Very little funerary evidence is available for the local Late Chalcolithic (Berikldeebi stage). We have first of all the single find of a partially plundered kurgan at Kavtiskhevi//oramisgora ${ }^{50}$ (Fig. 7).

184; Palumbi 2008: 107-156, 174-175.

${ }^{49}$ Ghambashidze/Mindiashvili/Gogochuri/Kakhiani/Japaridze 2010: 224, nos. 153-154.

${ }^{50}$ Makharadze 2007: 123-126; Makharadze 2008: 67, 100 f., figs. 33-34. 
This proves that this type of funerary construction, especially well known, in the early and mid- $4^{\text {th }}$ mill. $\mathrm{BC}$, from the rich barrows of the Maikop culture of the Northern Caucasus $^{51}$, but also attested in Azerbaijan ${ }^{52}$, was at least known, in the same period, in the Shida Karli region of Georgia ${ }^{53}$. The Kavtiskhevi kurgan appears very similar, for instance, in its layout, to kurgan no. 1 at Soyuk Bulaq in Azerbaijan ${ }^{54}$. This had a central stone chamber, which apparently hosted the remains of a single adult individual, and was equipped with a rich inventory of burial goods.

An infant burial in jar was found at Berikldeebi, level V2 ${ }^{55}$. This type of grave was common, in the Late Chalcolithic period, from Upper Mesopotamia ${ }^{56}$ to the Southern Caucasus: it is attested, for instance, at several sites in Azerbaijan ${ }^{57}$. As we anticipated, it was still sporadically present, in Georgia, in the earliest phase of the KA period ${ }^{58}$, but apparently went out of use later on.

We can therefore tentatively conclude that burial customs in the Shida Kartli region during the pre-KA phase were probably similar to those of the adjacent regions, that is they were characterised by uses (individual barrow graves for adults, jar burials for infants and young children), strongly divergent from those attested in the same region during the KA period.

The same can be said, based on more solid evidence, for the following post-KA (Early Kurgan) period. Like elsewhere in Georgia and in other regions of the Southern Caucasus, this is characterised in Shida Kartli by a generalised diffusion of barrow graves ${ }^{59}$. Martqopi/Bedeni kurgans are known from eight different sites in the region: Bebnisi (two Bedeni kurgans) ${ }^{60}$, Tedotsminda (a Martqopi kurgan $)^{61}$, Kheltubani (one Martqopi/Bedeni kurgan and two Bedeni kurgans) $)^{62}$, Khovle

${ }^{51}$ For a recent synthesis on the Maikop culture, see Ivanova 2013: 50-129.

${ }^{52}$ Lyonnet/Akhundov/Almamedov 2008.

53 On Late Chalcolithic kurgans in the Southern Caucasus, see also Poulmarc'h 2014: 343-364.

${ }^{54}$ Lyonnet/Akhundov/Almamedov 2008: 28-32.

55 Sagona 2014: 35; see also Kakhiani/Sagona/Sagona/Kvavadze/ Bedianashvili/Massager/Marti/Herrscher/Martkoplishvili/Birkett-Rees/Longford 2013: 17, fn. 37.

${ }^{56} \mathrm{~A}$ recent review of infant graves in Mesopotamia in the late $5^{\text {th }}$ and $4^{\text {th }}$ millennia BC can be found in Brereton 2013. For Arslantepe on the Turkish Euphrates, see Frangipane 2007-2008: 170-173. More in general, see also Poulmarc'h 2014: 343.

${ }^{57}$ E.g. at Ovçular Tepesi, Leilatepe, Böyük Kesik, Alkhantepe and Poylu (Poulmarc'h 2014: 341-343; Kakhiani/Sagona/Sagona/ Kvavadze/Bedianashvili/Massager/Marti/Herrscher/Martkoplishvili/Birkett-Rees/Longford 2013: 17, fn. 57; Sagona 2014: 41 with further literature).

${ }^{58}$ See above, fn. 46.

${ }^{59}$ Rova 2014: 62; for an extended discussion, see Carminati 2017.

${ }^{60}$ Jalabadze/Ghlonti/Kroidze/Ketskhoveli/Chilashvili 2012: 9093, figs. 48-52.

${ }^{61}$ Mindiashvili/Murvanidze/Ramishvili/Chikovani 2003: 65-69.

${ }^{62}$ Mindiashvili 1984: 1985. (a Martqopi/Bedeni kurgan) $)^{63}$, Doesi (a Bedeni Kurgan) ${ }^{64}$, Katriani (two Bedeni kurgans) ${ }^{65}$, Okherakhevi (a Bedeni kurgan) ${ }^{66}$ and Akhali Nicbisi (two Martqopi kurgans) ${ }^{67}$.

Shida Kartlian kurgans (Fig. 8) are smaller in size (they do not exceed $30 \mathrm{~m}$ in diameter) than contemporary kurgans from Eastern and Southern Georgia ${ }^{68}$, and contain more modest burial goods. The mounds are made of stones and/or earth, and generally have a low underground or overground chamber; they generally host one (or two) skeletons; "cenotaphs" or kurgans containing only a few fragments of bones are also attested ${ }^{69}$. Grave inventories are represented by a small number of pottery vessels associated with few metal (weapons, pins) and lithic objects; in four cases $^{70}$, traces of wheel-furrows were detected on the floor of the burial chamber. Although on a more modest scale, these kurgans apparently attest to phenomena (large investment of workforce in grave construction, wagon-accompanied funeral processions etc.) similar to those that characterise the EK period in other regions, where they are generally seen as evidence for the emergence of tribal leaders.

\section{KURA-ARAXES KURGANS IN SHIDA KARTLI}

We can now come back to examine the limited evidence for KA kurgans in the Shida Kartli region. We are here faced with a problem, namely the fact that the same definition of kurgan (funeral barrow) is not so univocal as one may think ${ }^{71}$. Therefore, in the case of older excavations, which often have no attached graphic documentation, it is not always easy to understand which type of structures one is dealing with.

$\overline{63}$ Japaridze 1998: 148-150.

${ }^{64}$ Shatberashvili 1976: 55; see also Japaridze 1992: 213.

${ }^{65}$ Makharadze 2008: 67, 102-104, figs. 35-37.

${ }^{66}$ Rova/Puturidze/Makharadze 2011: 18-22, figs. 11-14.

${ }^{67}$ Apakidze/Nikolaishvili/Narimanishvili/Davlianidze/Sadradze/ Khetsuriani/Iremashvili/Noneishvili 1995: 89, pl. 176; Apakidze/Nikolaishvili/Giunashvili/Davlianidze/Narimanishvili/ Sadradze/Dzneladze/Iremashvili/Chezuriani/Noneishvili/Gavasheli 2004: 78-79, pls. CXLV-CXLVII.

${ }^{68}$ For a general description, see Miron/Orthmann 1995: 69-78; for some recent discoveries: Makharadze/Murvanidze 2014a Makharadze/Murvanidze 2014b; Makharadze/Kalandadze/ Murvanidze 2016.

${ }^{69}$ Kurgan no. 1 at Okherakhevi, for instance, contained only tiny fragments of human bones, including one incisor tooth belonging to an adult individual (Rova/Puturidze/Makharadze 2011: 21 , fn. 58).

${ }^{70}$ Tedotsminda, kurgan no. 1 at Bebnisi, kurgans nos. 2 and 4 at Kheltubani.

${ }^{71}$ M. Poulmarc'h for instance (Poulmarc'h 2014: 42, tableau 3, 97, fig. 32; see Poulmarc'h/Pecqueur/Jalilov 2014: 232, fig. 1) considers as discriminant feature the presence of a "cover of pebbles forming a circle of which the minimum diameter is $5 \mathrm{~m}$ ", while other scholars apparently reserve the term "kurgan" only for larger barrows. 


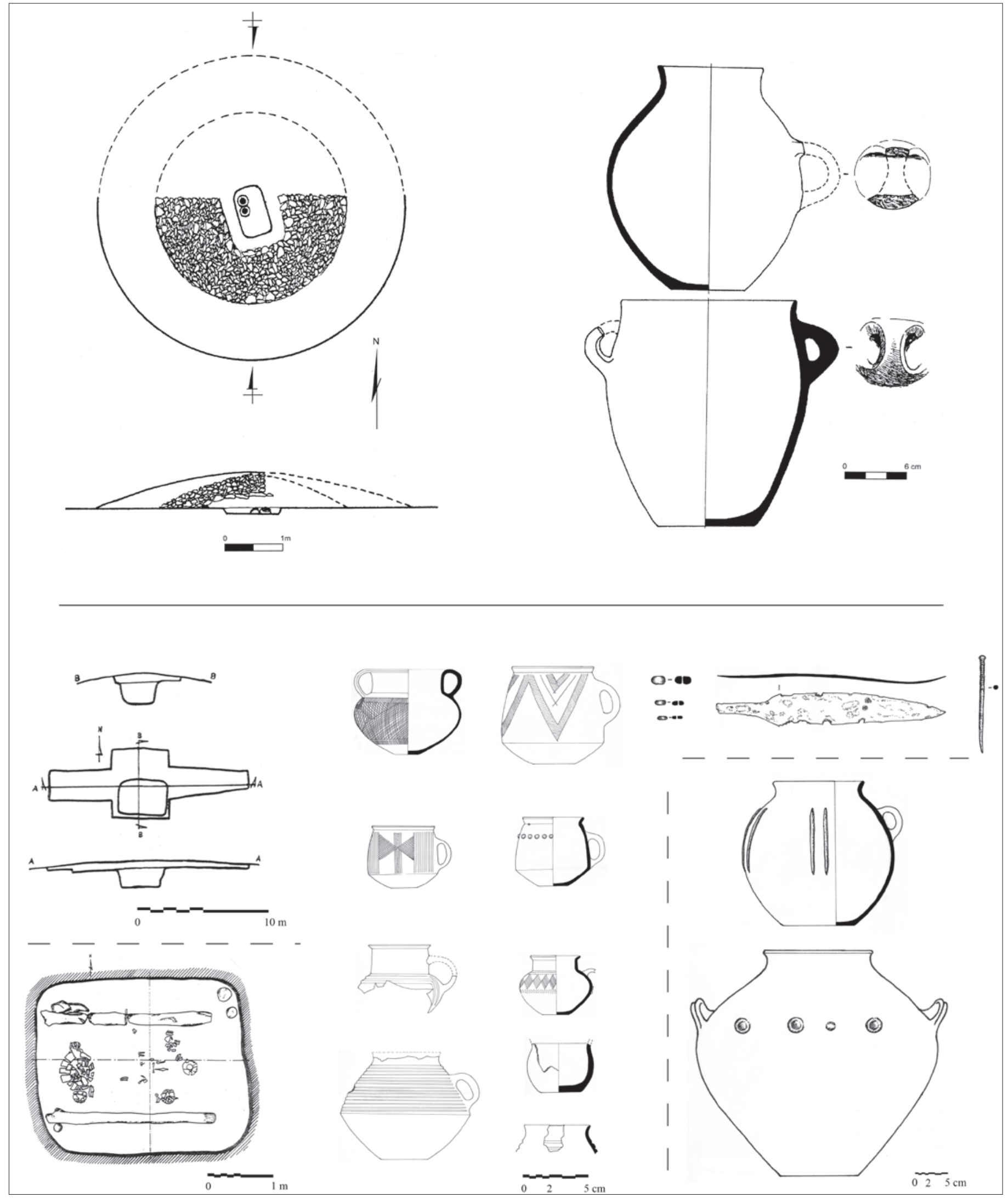

Figure 8: EK Kurgans from the Shida Kartli Region: Katriani, Kurgan no. 2, Above (from Makharadze 2008: Figs. 36-37); Bebnisi Kurgan No. 1, Below (from Puturidze/Rova 2012: Figs. 48-50). / Shida Kartli Bölgesi Ek Kurganlarl: Katriani, 2 No'lu Kurgan, Yukarlda (Makharadze 2008: Figs. 36-37); Bebnisi 1 No'lu Kurgan, Aşağıda (Puturidze/Rova 2012: Figs. 48-50). 


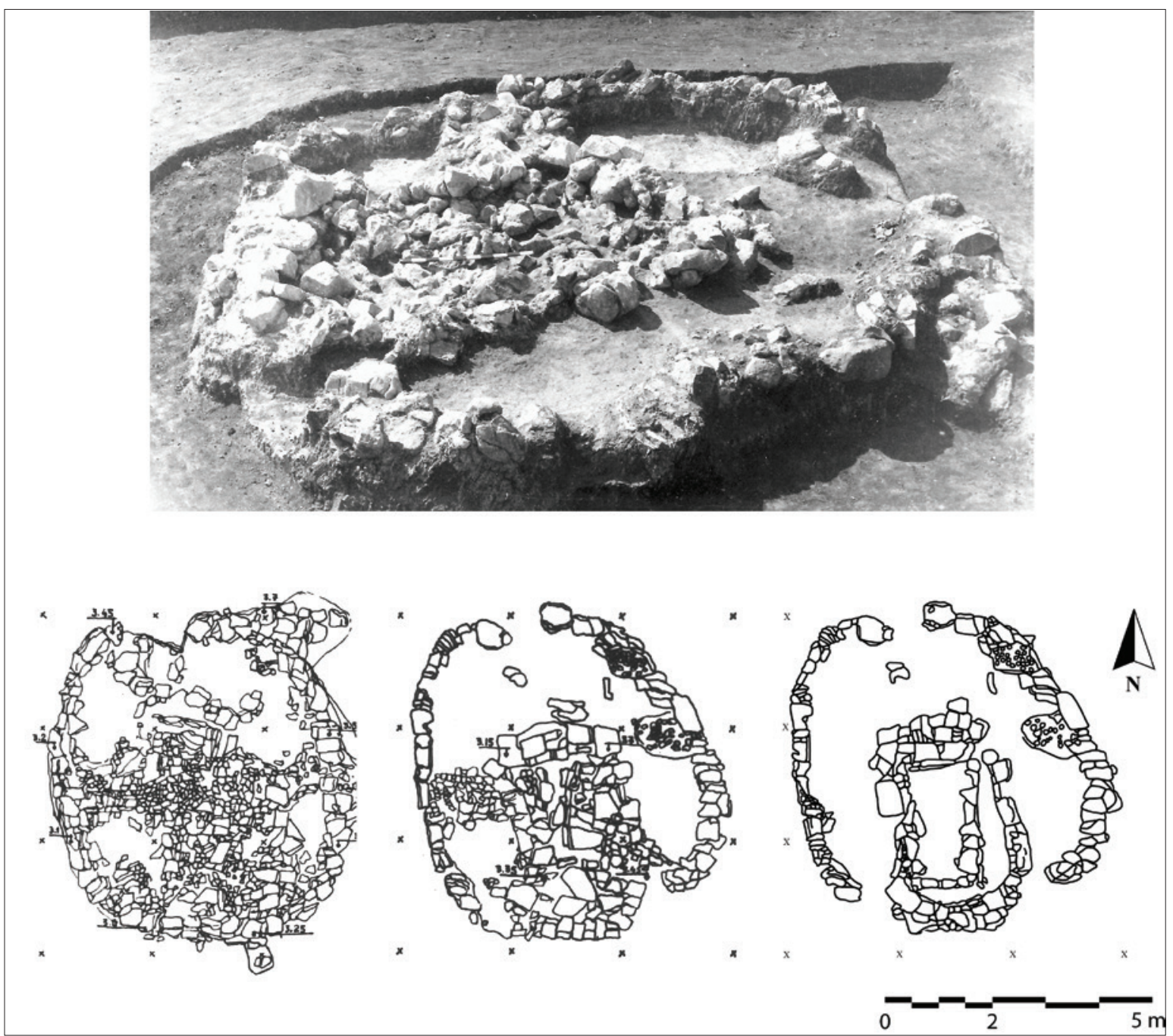

Figure 9: Grave No. 355 at Natsargora (from Puturidze/Rova 2012: Pl. 18,1; Figs. 4, 5A). / Natsargora 355 No'lu Mezar (Puturidze/Rova 2012: Pl. 18,1; Figs. 4, 5A).

Grave n. 355 at Natsargora ${ }^{72}$ (Fig. 9) was described by the excavators as a chamber grave covered by a group of stones, but it might be equally defined as a small kur$\operatorname{gan}^{73}$. It was sub-circular in shape, delimited by a circle of stones measuring $6 \times 6.5 \mathrm{~m}$. In its centre there was a rectangular stone-lined chamber, which contained the remains of 7 different individual. These lay at different levels of the filling; some of the skeletons were complete, apparently in anatomical connection, and lay in crouched position on one side. This grave was very different in shape from the other KA graves of Natsargora; in addition, it was the only collective grave of this cemetery. Burial goods (Fig. 10) consisted of six pottery vessels, a metal bracelet, a metal pin, and four flint arrowheads. They were not more numerous than those of the other graves if one considers the number of the grave's occupants; pottery was very similar to that of the rest of the

\footnotetext{
${ }_{72}$ Puturidze/Rova 2012: 18-20, figs. 4-5, pls. 17-19.

${ }^{73}$ In fact, it would fit Poulmarc'h definition of a kurgan (see above, fn. 71) and was accordingly classified as a kurgan by this author (Poulmarc'h 2014: 98, tableau 13, cf. vol. 3: 245).
}

cemetery, although it might have been slightly later in date $^{74}$. One may therefore be tempted to consider this grave as evidence for a transitional stage, in which kurgan-like structures were introduced in the area, at first for collective burials.

Does this, however, really fit with the remaining evidence? Three KA kurgans, none of which is illustrated in available publications, were excavated in 1938-1940 by $\mathrm{S}$. Makalatia at Tquiavi in the Gori district ${ }^{75}$. They were very similar to each other in construction, had a diameter of $15-20 \mathrm{~m}$, and their height amounted to $0.60-1 \mathrm{~m}$. Pottery is said to have had rather archaic features (it would date to the late KA I/early KA II phase), which is confirmed by a quick examination, by the present author, of the items exhibited in the new Gori Museum.

\footnotetext{
${ }^{74}$ See Puturidze/Rova 2012: 46 et passim, for discussion.

75 Jalabadze/Ghlonti/Kroidze/Ketskhoveli/Chilashvili 2012: 90; see also Japaridze 1961: 271-272; Japaridze 1992: 190.
} 


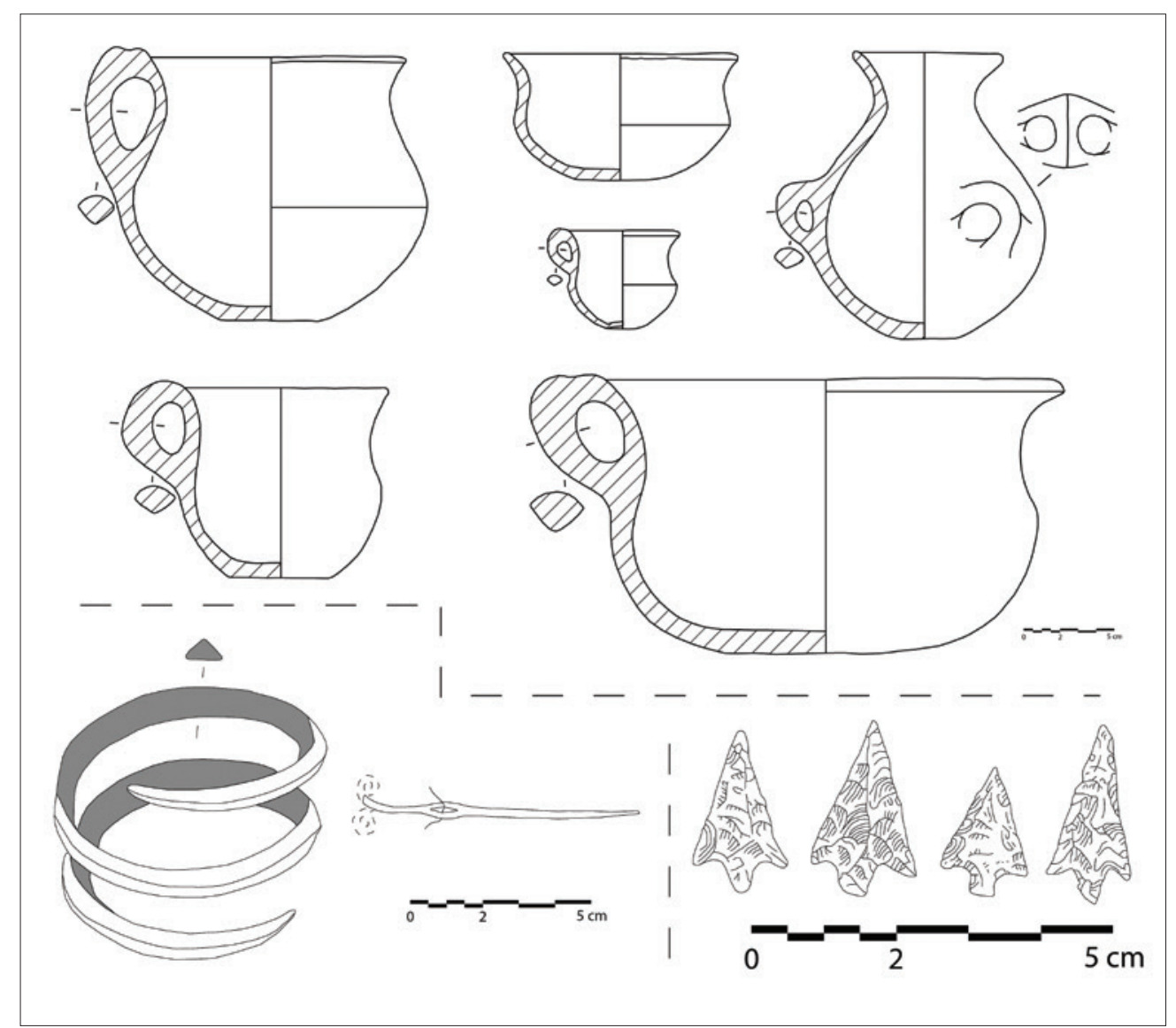

Figure 10: Burial Goods from Grave no. 355 at Natsargora (from Puturidze/Rova 2012, fig. 5B). / Natsargora 355 No 'lu Mezardan Gömü Hediyeleri (Puturidze/Rova 2012, fig. 5B).

42 corpses were discovered, mostly without accompanying goods, in different positions and at different levels, in kurgan no 1 . This therefore represented a collective grave, although is not possible to understand if the bodies had been buried in individual pits, as it would appear from the excavators' description, or if all of them lay in the main chamber, as is often the case, for instance, in KA kurgans in Azerbaijan ${ }^{76}$.

The second kurgan, however, was an individual grave; burial goods were not especially rich, but included a stone macehead (a possible status symbol?) and a copper needle; while the third kurgan hosted two individuals and was equipped with a pottery vessel and some hair-rings. So, the evidence from Tqviavi supports neither the idea that kurgans came into use in the region late in the KA period, nor the idea that they were exclusively used for collective graves.

Finally, some attention should be devoted to the kurgans from the Sachkhere district in the upper valley of the Kvirila River, at the north-eastern edge of the Imereti

\footnotetext{
${ }^{76}$ See for instance the kurgans from Mentesh Tepe and Uzun Rama illustrated in Poulmarc'h/Pecqueur/Jalilov 2014.
}

province, since these are generally attributed to the (late) KA period, and their material culture is said to be very close to that of Shida Kartli. These kurgans attracted considerable attention because of their remarkable metal finds ${ }^{77}$, but represent especially problematic finds, since they were dug by different excavators between 1910 and 1955 , and were only partially published ${ }^{78}$.

Their very number is uncertain: mention is made from finds at three different locations (Tsartsis Gora, Nacherkezevi and an anonymous kurgan) in the urban territory of Sachkhere, and two (Koreti and Pasieti) near the village of Koreti ca $5 \mathrm{~km}$ to the SW, but it is not clear from the descriptions whether at each of them only a single kurgan was found, as it would seem, to judge from the illustrations, in the case of $\mathrm{Koreti}^{79}$ (Fig. 11), or more than one, as maybe at Tsartsis Gora ${ }^{80}$ (Fig. 12).

\footnotetext{
${ }^{77}$ A recent complete publication of the metal finds can be found in Ghambashidze/Mindiashvili/Gogochuri/Kakhiani/Japaridze 2010 .

${ }^{78}$ Kuftin 1949: 64-82; Japaridze 1961: 122-203, 277-282; see also Japaridze 1992: 235-237.

${ }^{79}$ Kuftin 1949: 80, fig. 32, pl. LXVI.

${ }^{80}$ Ibid.: 68-69, fig. 28, pl. LIV.; Japaridze 1961: figs. 21, 22, 25-28, 40-41, pls. XXI-XXIV.
} 


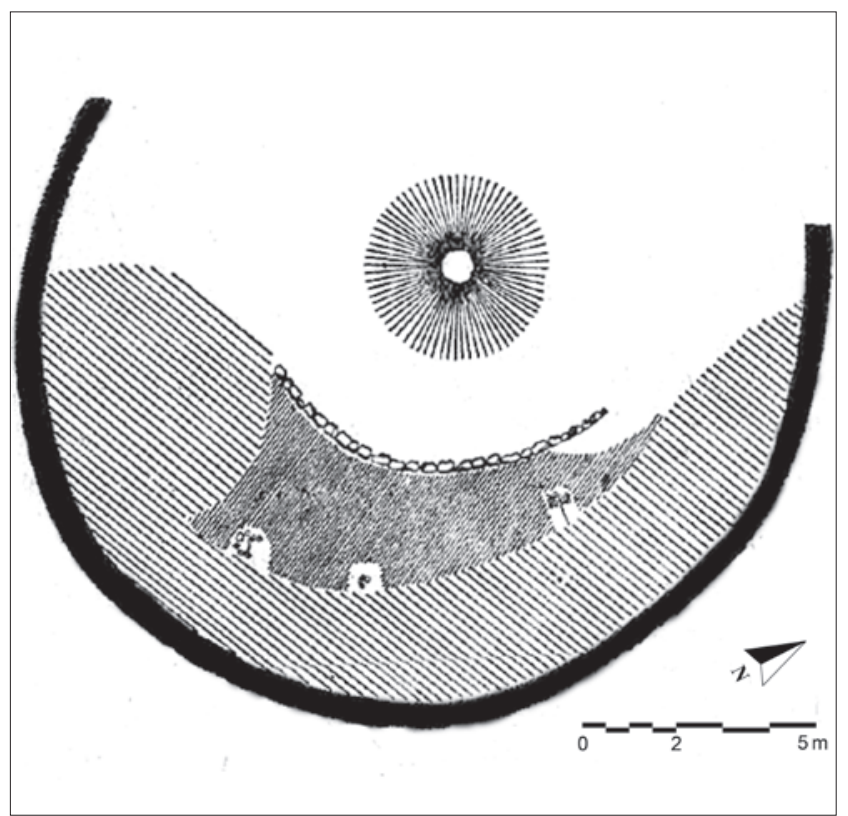

Figure 11: Plan of Koreti Kurgan (from Kuftin 1949: Fig. 32). / Koreti Kurganı Planı (Kuftin 1949: Fig. 32).

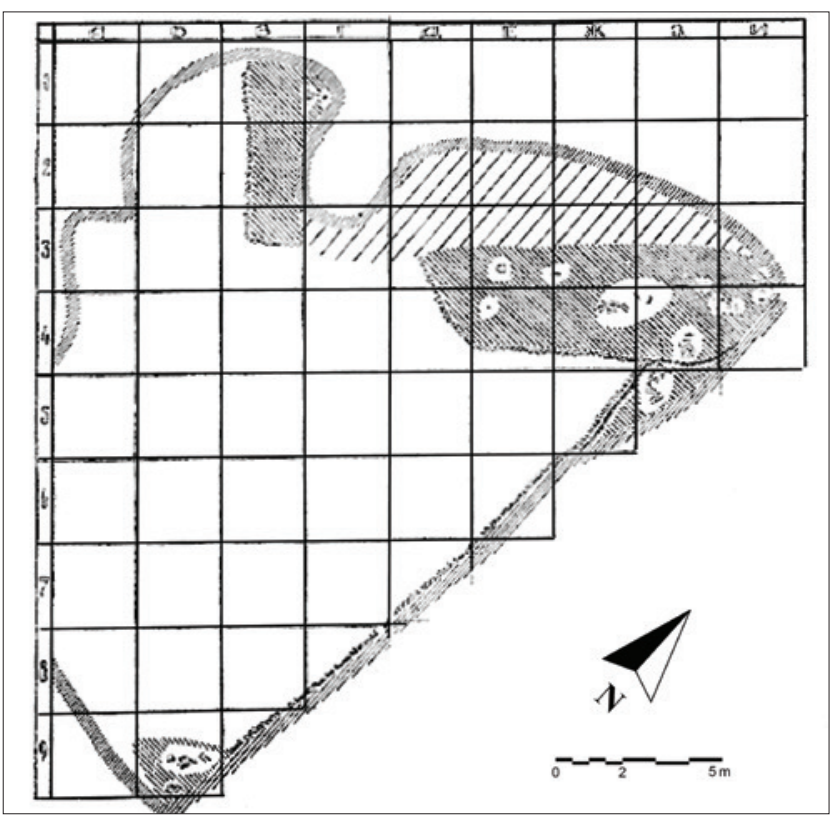

Figure 12: Plan of Tsartsis Gora Kurgan (from Kuftin 1949: Fig. 28). / Tsartsis Gora Kurganı Planı (Kuftin 1949: Fig. 28).

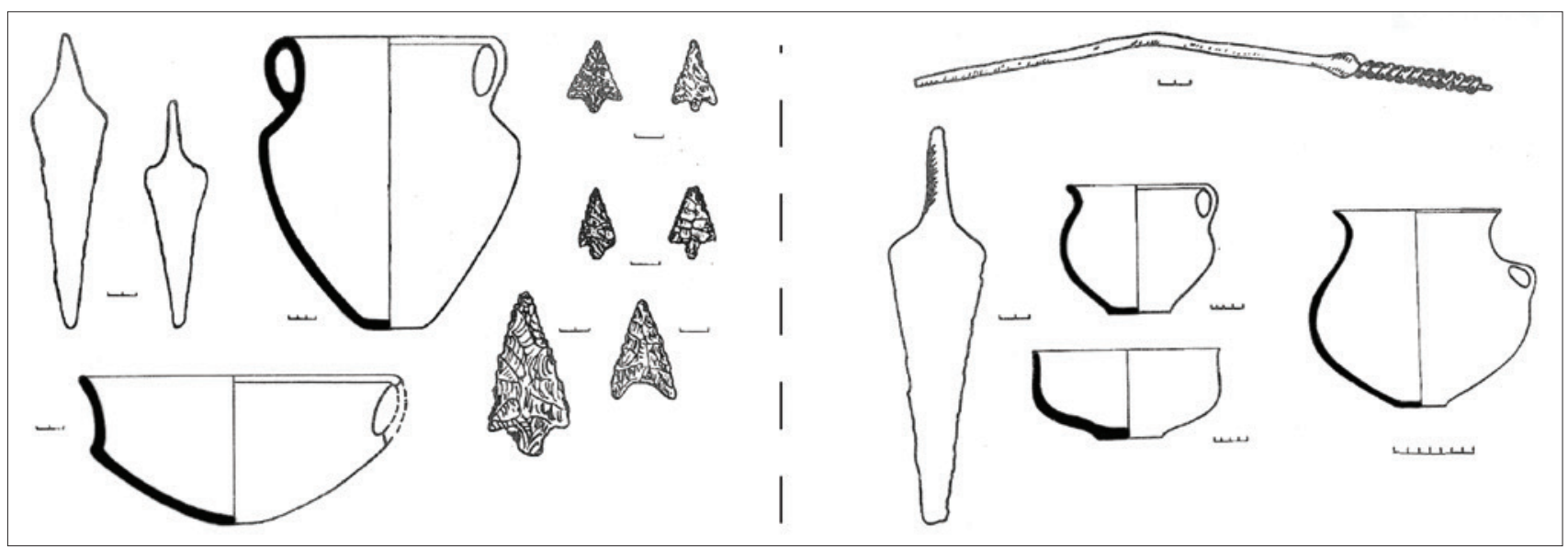

Figure 13: Burial Goods from Nacherkhezevi Kurgan, Burial No. 3 (Left), and Tsartsis Gora Kurgan, Burial No. 1 (Right) (from Japaridze 1992: Pl. CLXXI). / Nacherkhezevi Kurganı Gömü Hediyeleri, 3 No’lu Gömü (Sol), ve Tsartsis Gora Kurgan, 1 No’lu Gömü (Sağ) (Japaridze 1992: Pl. CLXXI).

Be that as it may, one is clearly dealing with large artificial stone mounds, in which a considerable number of stone-covered pit graves (up to 27 at Nacherkhezevi) had been dug at different levels. As far as they were not disturbed and could be separately excavated, these were mostly individual graves in which the dead had been buried on one side in crouched position with a small set of burial goods (Fig. 13). It is unclear whether there ever was a main burial, significantly different in wealth from the other ones, in these kurgans. So, it seems that the apparent wealth of the Sachkhere kurgans derives from lumping together the assemblages from different individual graves, and that these were not much richer, in themselves, than the average graves of the Shida Kartli region.
Finally, it has to be considered that the Sachkhere kurgans were obviously used for a considerable lapse of time, which extends well into the Early Kurgan period. The majority of published pottery is actually of KA type ${ }^{81}$, and is very similar to the Shida Kartli standard assemblage: in general terms, it should be attributed to the late (KA III) phase of the culture. From the same kurgans come, however, also later (Martqopi/Bedeni) ceramic material. Burial 1 in the Pasieti kurgan $^{82}$, for instance (Fig. 14), is clearly to be attributed to the Bedeni period. In any case, in the absence of a clear distinction and chronological attribution of individual burials, evidence from the Sachkhere kurgans cannot be considered as typical for KA funerary customs in the area.

\footnotetext{
${ }^{81}$ Kuftin 1949: Figs. 30, 31, 33, pls. LXI-LXIII, LXIX.

82 Japaridze 1961: 138-139, fig. 29.
} 


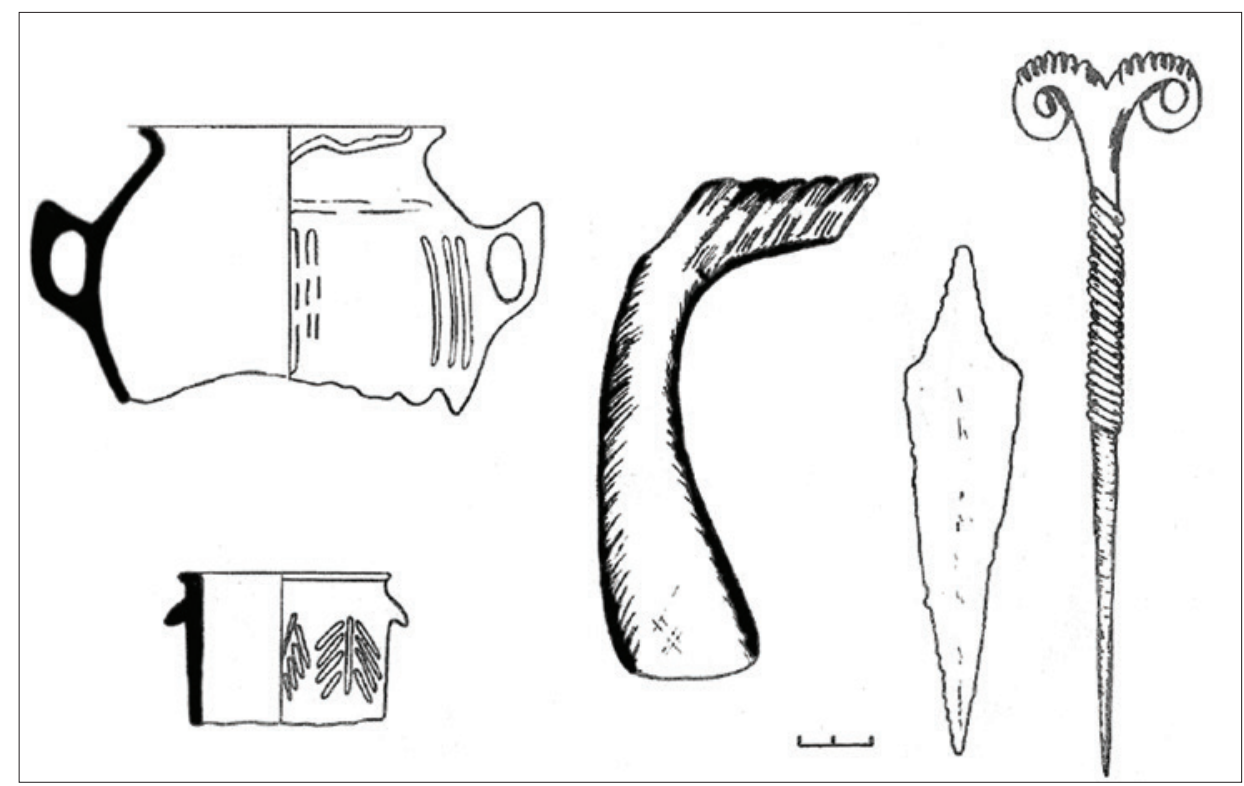

Figure 14: Burial Goods from Pasieti Kurgan, Burial No. 1 (From Japaridze 1992: Pl. CLXXII, 2). / Pasieti Kurgan, 1 No'lu Gömü Hediyeleri (Japaridze 1992: Pl. CLXXII, 2).

\section{CONCLUSIONS}

The data presented above essentially confirm the view that KA burial customs in Shida Kartli deeply differed in several respects from those both of the previous Late Chalcolithic and of the following Early Kurgan period: a) in the preference for individual pit graves, $b$ ) in the scarce differentiation of burial goods and, c) in the different treatment of newborn and young children.

Compared to other regional variants of the KA culture, the Shida Kartli variant stands out for a remarkable homogeneity in burial customs. Graves were usually located in "extra-moenia" cemeteries situated in close proximity to the contemporary settlements, and typically consisted of pit graves, often covered by an irregular group of stones, which hosted an adult individual accompanied by a modest set of gravegoods: a small number of pottery vessels and/or a few personal ornaments. Double/triple burials are not uncommon, but multiple graves are quite rare, as are depositions of newborn and young children, which are sometimes associated with adult graves. The scarce differentiation of burial goods conveys the idea of a fundamentally egalitarian society, or at least of a society in which differences in status, if existing at all, were not purposely emphasised.

On the other hand, the pre-KA Late Chalcolithic phase in the region appears to have been characterised by the use of individual barrow graves for adults and of intramural jar burials for newborn and young children, while the following Early Kurgan period witnesses the generalised diffusion of kurgans and the appearance in the region of elite burials emphasising differences in status, though apparently on a lesser scale than in other region of the Southern Caucasus.
Kurgans (or kurgan-like burials) are attested in Shida Kartli during the KA period, but - contrary to other regional variants of the KA culture -, they are very rare there. Within the KA period, they are present since a rather early phase (KA I-II: Tqviavi, maybe also Natsargora grave no. 355), but their frequency appears to have increased, at least in the Sachkhere area, in the latest (KA III) phase. They appear to have significantly differed from each other in their details: for instance, some of them were provided with a single funerary chamber which hosted different individuals, while others were the location of several pit graves. On the basis of the available documentation, it is however impossible to classify them into different types. With one possible exception (kurgan no. 2 at Tqviavi), they were apparently not used, like in both the Late Chalcolithic and in the Early Kurgan periods, as individual high status graves, but rather as collective family burials, as is often the case for KA kurgans in other regions of the Southern Caucasus as well.

Although at first sight KA kurgan graves may appear more richly equipped than standard pit graves, if one considers the number of the grave's occupants, this wealth appears to be illusory. In fact, in the few cases where burial goods could be attributed to different individuals buried in the same kurgan, they did not show any significant difference, and were furthermore well comparable, in quantity as well as in quality, to the equipment of contemporary individual graves of different typology. Furthermore, it is interesting to observe that a number of KA kurgans in Shida Kartli seem to have been used as a location for individual pit graves not much different from standard KA graves in the region, i.e. as sort of small "cemeteries", possibly used by distinct kinship groups, a custom which in the Sachkhere area apparently continued during the following Early Kurgan period as well. 


\section{BIBLIOGRAPHY}

\section{AKHUNDOV, T. 2007}

"Sites de migrantes venus du Proche-Orient en Transcaucasie, in Les cultures du Caucase (VIe-IIIe mill. avant notre ère): leurs relations avec le Proche-Orient (Ed. B. Lyonnet). Paris: 95-121.

APAKIDZE, A.M./NIKOLAISHVILI, V.V./NARIMANISHVILI, G.K./DAVLIANIDZE, R.V./SADRADZE, V.G./ KHETSURIANI, L.G./IREMASHVILI, SH.A./ NONEISHVILI, A.I. 1995

"Mtskhetskaja Ekspetsija" (Mtskheta Expedition), Polevije Arkheologicheskie Issledovanija v 1987 godu (Archaeological Field Investigations in 1987): 83-89 (in Russian).

APAKIDZE, A./NIKOLAISHVILI, V./GIUNASHVILI, G./DAVLIANIDZE, R./NARIMANISHVILI, G./ SADRADZE, V./ DZNELADZE, M./IREMASHVILI, SH./CHEZURIANI, L./NONEISHVILI, A./GAVASHELI, E. 2004

"Mtskhetis Ekspeditsia" (Expedition von Mzcheta), Savele arqeologiuri kvleva-dzieba 1989-1992 tslebshi (mokle angarishebi) (Archäologische Geländearbeiten in Georgien 1989-1992): 70-81 (in Georgian with German summary).

\section{BERTRAM, J.-K. 2003}

Grab- und Bestattungssitten des späten 3. und 2. Jahrtausends v. Chr. im Kaukasusgebiet. Wilkau-Haßlau.

\section{BERTRAM, J.-K. 2005}

"Probleme der ostanatolischen/südkaukasischen Bronzezeit: ca. 2500-1600 v. u. Z.”, TÜBA-AR 8: 61-84.

\section{BERTRAM, J.-K. 2010}

"Zum Martqopi-Bedeni-Horizont im Südkaukasusgebiet", in Von Majkop bis Trialeti - Gewinnung und Verbreitung von Metallen und Obsidian in Kaukasien im 4.-2. Jts. v. Chr. (Eds. S. Hansen / A. Hauptmann / I. Motzenbäcker / E. Pernicka) (Kolloquien zur Vor- und Frühgeschichte 13). Bonn: 253-261.

\section{BRERETON, G. 2013}

"Cultures of Infancy and Capital Accumulation in Pre-urban Mesopotamia”, World Archaeology 45:2: 232-251.

\section{CARMINATI, E. 2017}

"The Martqopi and Bedeni Components of the Early Kurgan Complex in Shida Kartli (Georgia): A Reappraisal of the Available Data", in At the Northern Frontier of Near Eastern Archaeology: Recent Research on Caucasia and Anatolia in the Bronze Age (Proceedings of the Humboldt Kolleg Venice, 09-12/01/2013) (Eds. E. Rova / M. Tonussi) (Subartu 38). Turnhout: 173-188.

\section{CHATAIGNER, C./PALUMBI, G. (Eds.) 2014}

The Kura-Araxes Culture from the Caucasus to Iran, Anatolia and the Levant. Between Unity and Diversity (= Paléorient 40.2 thematic issue).

\section{CHILASHVILI, L. 1964}

Naqalaqari Urbnisi (The Urban Site of Urbnisi). Tbilisi (in Georgian with Russian summary).

\section{FRANGIPANE, M. 2007-2008}

"The Arslantepe «Royal Tomb»: New Funerary Customs and Political Changes in the Upper Euphrates Valley at the Beginning of the Third Millennium BC", Scienze dell'Antichità 14/1: 169-194.

FRANGIPANE, M./DI NOCERA, G.M./HAUPTMANN, A./MORBIDELLI, P./PALMIERI, A.M./SADORI, L./ SCHULTZ, M./SCHMIDT-SCHULTZ, T. 2001

"New Symbols of a New Power in a "Royal" Tomb from 3000 BC Arslantepe, Malatya (Turkey)", Paléorient 27/2: 105-139.

\section{GAGOSHIDZE, I. 2012}

"Doghlauri (Aradetis Orgora) Cemetery", Online Archaeology 3: 12-19 (http://heritagesites.ge/files/Axali\%20 Jurnali\%203\%20iEnglish/, last consulted 11/2013.

\section{GAGOSHIDZE, I./ROVA, E. 2018}

"New Investigations at Aradetis Orgora, a Multiperiod Centre of the Shida Kartli Region in Georgia", in Context and Connection: Essays on the Archaeology of the Ancient Near East in Honour of Antonio Sagona (Eds. A. Batmaz / G. Bedianashvili / A. Michalewicz / A. Robinson), (Orientalia Lovaniensia Analecta 268), Leuven: 521-546.

\section{GELASHVILI, B. 2014}

"Gviandeli brinjaos khanis iaraghebi doghlauris samarovnidan" (Late Bronze Age Weapons from the Doghlauri Cemetery), Online Archaeology 6: 203-215 (in Georgian). (http://www.heritagesites.ge/upload/file/1431005127.pdf, last consulted 11/2013). 
GHAMBASHIDZE，I./MINDIASHVILI，G./GOGOCHURI, G./KAKHIANI, K./JAPARIDZE, I. 2010

Udzvelesi metalurgia da samto saqme Saqartveloshi $d z v$. ts. VI - III atastsleulebshi (Alte Metallurgie und Bergbau in Georgien in 6.-3. Jt. v. Chr.). Tbilisi (in Georgian).

GLONTI, L./KETSKHOVELI, M./PALUMBI, G. 2008

"The Cemetery at Kvatskhelebi", in Archaeology in Southern Caucasus: Perspectives from Georgia (Eds. A. Sagona / M. Abramishvili) (Ancient Near Eastern Studies Supplement 19). Leuven, Paris, Dudley, MA: 153-184.

HANSEN, S./HAUPTMANN, A./MOTZENBÄCKER, I./PERNICKA, E. (EDS.) 2010

Von Majkop bis Trialeti. Gewinnung und Verbreitung von Metallen und Obsidian in Kaukasien im 4.-2. Jt. v. Chr. (Kolloquien zur Vor- und Frühgeschichte 13). Bonn.

IVANOVA, M. 2013

The Black Sea and the Early Civilizations of Europe, the Near East and Asia. Cambridge.

JALABADZE， M./GHLONTI， L./KORIDZE， I./ KETSKHOVELI, M./CHILASHVILI, I. 2012

"Early Bronze Age Cemeteries from Shida Kartli (Kura-Araxes, Bedeni)", in Khashuri Natsargora: The Early Bronze Age Graves (Eds. M. Puturidze / E. Rova) (Publications of the Georgian-Italian Shida Kartli Archaeological Project I) (Subartu 30). Turnhout: 59-94.

JALABADZE, M./PALUMBI, G. 2008

"Kura-Araxes Tombs at Takhtidziri", in Archaeology in Southern Caucasus: Perspectives from Georgia (Eds. A. Sagona / M. Abramishvili) (Ancient Near Eastern Studies Supplement 19). Leuven, Paris, Dudley, MA: 117-123.

\section{JAPARIDZE, O. 1955}

Litonis tsarmoebis adreuli sapekhuri saqartveloshi (The Early Phase of Metal Production in Georgia). Tbilisi (in Georgian with Russian summary).

\section{JAPARIDZE, O. 1961}

Kartveli tomebis istoriis litonis tsarmoebis adreul sapekhurze (On the History of Georgian Tribes in the Aeneolithic and Early Bronze Ages). Tbilisi (in Georgian).
JAPARIDZE, O. 1998

Kartveli tomebis etnokulturuli istoriisatvis dzv.ts. III atastsleulshi (adreqorghanuli kultura) (Zur ethnokulturellen Geschichte der georgischen Stämme im 3. Jahrtausend v. Chr.). Tbilisi (in Georgian with German summary).

\section{JAPARIDZE, O. (Ed.) 1992}

Sakartvelos arkeologia. v. II. Eneolit-adre brinjaos kha$n a$ (Archaeology of Georgia. Vol. II. The Eneolithic and Early Bronze Age). Tbilisi (in Georgian).

\section{JAVAKHISHVILI, A./GLONTI, L. 1962}

Urbnisi I: Kvatskhelebis (Tvlepia-Kokhis) Namosakhlarze 1954-1961 ts. Chatarebuli Gatkhrebi (Urbnisi I: Archaeological Excavations conducted at Kvatskhelebi (Tvlepia-Kokhi) in 1954-1961). Tbilisi (in Georgian with Russian summary).

KAKHIANI, K./SAGONA, A./SAGONA, C./KVAVADZE E./BEDIANASHVILI G./MASSAGER E./ MARTIN L./ HERRSCHER, E./MARTKOPLISHVILI, I./BIRKETT-REES, J./ LONGFORD, C. 2013

"Archaeological Investigations at Chobareti in Southern Georgia, the Caucasus", Ancient Near Estearn Studies 50: 1-138.

\section{KIKVIDZE, I. 1972}

Poselelenie Epoki Rannei Bronzi Khizanaant Gora (Early Bronze Age Settlement of Khizanaant Gora). Tbilisi (in Russian).

\section{KORIDZE, I.PALUMBI, G. 2008}

"Kura-Araxes Tombs at Aradetis Orgora" in Archaeology in Southern Caucasus: Perspectives from Georgia (Eds. A. Sagona, M. Abramishvili) (Ancient Near Eastern Studies Supplement 19). Leuven, Paris, Dudley, MA: 125-152.

\section{KUFTIN, B.A. 1949}

Arkheologicheskaiya marshrutnaiya ekspeditsia 1945 godu v iugo osetiyu I imetetiyu (Archaeological Expedition in South Ossetia and Imeretia in 1945). Tbilisi (in Russian).

\section{KUFTIN, B.A. 1974}

Arkheologicheskaiya marshrutnaiya ekspeditsija $\mathrm{v}$ basseine rek Liakhvi, Prone, Kvirili I srednego Rioni v 1951 godu (Archaeological Expedition in the Basin of the Rivers Liakhvi, Prone, Kvirila and Middle Part of Rioni in 1951), Vestnik gosudarstvennogo muzeya gruzii (Bulletin of the State Museum of Georgia), 30 B: 131-153 (in Russian). 


\section{KUSHNAREVA, K.KH. 1997}

The Southern Caucasus in Prehistory: Stages of Cultural and Socio-Economic Development from the Eight to the Second Millennium B.C. (University Museum Monograph 99). Philadelphia.

LYONNET, B. (Ed.) 2007

Les cultures du Caucase (VIe-IIIe millénaires avant notre ère). Leurs relations avec le Proche-Orient. Paris.

LYONNET, B./AKHUNDOV, T./ALMAMEDOV, K. 2008

"Late Chalcolithic Kurgans in Transcaucasia. The Cemetery of Soyuk Bulaq (Azerbaijan)", AMIT 40: 27-44.

MAKHALATIA, S. 1943

Tqviavis qhorghanuli samarkhebis arqeologiuri gatkhrebi (Archaeological Excavations of the Tqhviavi Kurgan Burials). Tbilisi (in Georgian with Russian summary).

\section{MAKHARADZE, Z. 2007}

"Nouvelles données sur le Chalcolithique en Géorgie orientale", in Les cultures du Caucase (VIe-IIIe millénaires avant notre ère). Leurs relations avec le Proche-Orient (Ed. B. Lyonnet). Paris: 123-132.

\section{MAKHARADZE, Z. 2008}

"The Settlement of Tsikhiagora and the Early Barrows at Kavtiskhevi", in Archaeology in Southern Caucasus: Perspectives from Georgia (Eds. A. Sagona / M. Abramishvili) (Ancient Near Eastern Studies Supplement 19). Leuven, Paris, Dudley, MA: 63-104.

\section{MAKHARADZE, Z./MURVANIDZE, B. 2014A}

"Korgan "Tchintchrianis Gora"” (Kurgan "Tchintchrianis Gora"), Dziebani 22: 69-90 (in Georgian with English summary).

MAKHARADZE, Z./MURVANIDZE, B. 2014B

“Ananauris \# 3 didi korgani” (Ananauri № 3 Big Kurgan), Dziebani 22: 2014: 50-68 (in Georgian with English summary).

MAKHARADZE， Z./KALANDADZE， N./MURVANIDZE, B. (Eds.) 2016

Ananauri Big Kurgan 3. Tbilisi.
MINDIASHVILI, G. 1984

"Arkheologicheskaja Ekspeditsija v Sel. Kheltubani (Goriiskii Raion)" (Archaeological Expedition in the Kheltubani Village (Gori Region)), Polevije Arkheologicheskie Issledovanija v 1981 godu (Archaeological Field Investigations in 1981): 21-22 (in Russian).

\section{MINDIASHVILI, G. 1985}

"Arkheologicheskaja ekspeditsija Goriskogo raiona" (Archaeological Expedition in the Gori Region), Polevije Arkheologicheskie Issledovanija $v 1982$ godu (Archaeological Field Investigations in 1982): 36-37 (in Russian).

MINDIASHVILI，G./MURVANIDZE，B./RAMISHVILI, A./CHIKOVANI, G. 2003

"Arqeologiuri gatkhrebi (dzeglebi) dasavletis mimartulebis saeksporto milsadenis 143-e kilometrze" (Archaeological Excavations (Sites) Westwards of the Pipeline km 143), in Milsadeni Arqeologia II (Pipeline Archaeology II), Tbilisi: 65-94.

MIRON, A./ORTHMANN, W. (Eds.) 1995

Unterwegs zum Goldenen Vlies. Archäologische Funde aus Georgien. Saarbrücken.

\section{PALUMBI, G. 2007-2008}

"From Collective Burials to Symbols of Power. The Translation of Role and Meanings of the Stone-lined Cist Burial Tradition from Southern Caucasus to the Euphrates Valley", Scienze dell'Antichità 14/1: 141167.

\section{PALUMBI, G. 2008}

The Red and Black. Social and Cultural Interactions between the Upper Euphrates and Southern Caucasus Communities in the 4th and 3rd Millennium BC (Studi di Preistoria Orientale 2). Roma.

\section{POULMARC'H, M. 2014}

Pratiques funéraires et identité biologique des populations du Sud Caucase, du Néolithique à la fin de la culture Kura-Araxe (6ème - 3ème millénaire av. J.C.): une approche archéo-anthropologique (Unpublished $\mathrm{PhD}$ thesis Université Lumière Lyon 2).

POULMARC'H, M./PECQUEUR, L./JALILOV, B. 2014

"An Overview of Kura-Araxes Funerary Practices in the Southern Caucasus", Paléorient 40/2: 231-246. 
PUTURIDZE, M. 2012

"The Dynamic of Continuity in Ceramic Production at the Middle of the III Millennium B.C.", Studies in Caucasian Archaeology I: 12-70.

PUTURIDZE, M./ROVA, E. (Eds.) 2012

Khashuri Natsargora: The Early Bronze Age Graves (Publications of the Georgian-Italian Shida Kartli Archaeological Project I) (Subartu 30). Turnhout.

PUTURIDZE, M./ROVA, E. (Eds.) in preparation

Khashuri Natsargora: The Early Bronze Age Settlement (Publications of the Georgian-Italian Shida Kartli Archaeological Project III) (Subartu). Turnhout.

\section{RAMISHVILI, A. 2013 (Ed. B. MURVANIDZE)}

Natsargora. Adre brinjaos khanis namosakhlari da samarovani (Natsargora. Early Bronze Age Settlement and Cemetery) (Khashuris arkeologiuri ekspeditsiis shromebi VI) (Works of the Khashuri Archaeological Expedition VI). Tbilisi (in Georgian with English summary).

ROTHMAN, M.S. (Ed.) 2001

Uruk Mesopotamia \& Its Neighbors: Cross-cultural Interactions in the Era of State Formation. Santa Fe.

ROVA, E. 2014

"The Kura-Araxes Culture in the Shida Kartli Region of Georgia: An Overview", Paléorient 40/2: 45-67.

ROVA, E./PUTURIDZE, M./MAKHARADZE， Z. 2011

"The Georgian-Italian Shida Kartli Archaeological Project: A Report on the First Two Field Seasons 2009 and 2010", Rivista di Archeologia 34 (2010): 5-30.

ROVA, E./MAKHARADZE，Z./PUTURIDZE， M. 2017

"Khashuri Natsargora: New Research on the Kura-Araxes and Bedeni Cultures in Central Georgia", in At the Northern Frontier of Near Eastern Archaeology: Recent Research on Caucasia and Anatolia in the Bronze Age (Publications of the Georgian-Italian Shida Kartli Archaeological Project, 2) (Proceedings of the international Humboldt-Kolleg Venice, January 9 th -January 12th, 2013) (Eds. E. Rova / M. Tonussi) (Subartu 38), Turnhout: 153-171.
ROVA, E./TONUSSI, M. (Eds.) 2017

At the Northern Frontier of Near Eastern Archaeology: Recent Research on Caucasia and Anatolia in the Bronze Age (Proceedings of the Humboldt Kolleg Venice, 09-12/01/2013) (Subartu 38). Turnhout.

SAGONA, A. 2004

"Social Boundaries and Ritual Landscapes in Late Prehistoric Trans-Caucasus and Highland Anatolia", in A View from the Highlands. Archaeological Studies in Honour of Charles Burney (Ed. A. Sagona) (Ancient Near Eastern Studies Supplement 12). Leuven, Paris, Dudley, MA: 475-538.

SAGONA, A. 2014

"Rethinking the Kura-Araxes Genesis", Paléorient 40/2: 23-46.

SAGONA, A./ABRAMISHVILI, M. (Eds.) 2008

Archaeology in Southern Caucasus: Perspectives from Georgia (Ancient Near Eastern Studies Supplement 19). Leuven, Paris, Dudley, MA.

\section{SHATBERASHVILI, Z. 1976}

"Raskopki Kurganov Doesi i Okhera" (Excavations of Kurgans in Doesi and Okhera), Polevije Arkheologicheskie Issledovanija v 1974 godu (Field Archaeological Research in 1974): 55-56 (in Russian). 